\title{
Prevention of Plasticity of Endocannabinoid Signaling Inhibits Persistent Limbic Hyperexcitability Caused by Developmental Seizures
}

\author{
Kang Chen, ${ }^{1}$ Axel Neu, ${ }^{1}$ Allyson L. Howard, ${ }^{1}$ Csaba Földy, ${ }^{1}$ Julio Echegoyen, ${ }^{1}$ Lutz Hilgenberg, ${ }^{1}$ Martin Smith, ${ }^{1}$ \\ Ken Mackie, ${ }^{2}$ and Ivan Soltesz ${ }^{1}$ \\ ${ }^{1}$ Department of Anatomy and Neurobiology, University of California, Irvine, California 92697, and 2Department of Anesthesiology, University of \\ Washington, Seattle, Washington 98195
}

\begin{abstract}
Depolarization-induced suppression of inhibition (DSI) is an endocannabinoid-mediated short-term plasticity mechanism that couples postsynaptic $\mathrm{Ca}^{2+}$ rises to decreased presynaptic GABA release. Whether the gain of this retrograde synaptic mechanism is subject to long-term modulation by glutamatergic excitatory inputs is not known. Here, we demonstrate that activity-dependent long-term DSI potentiation takes place in hippocampal slices after tetanic stimulation of Schaffer collateral synapses. This activity-dependent, longterm plasticity of endocannabinoid signaling was specific to GABAergic synapses, as it occurred without increases in the depolarizationinduced suppression of excitation. Induction of tetanus-induced DSI potentiation in vitro required a complex pathway involving AMPA/ kainate and metabotropic glutamate receptor as well as CB1 receptor activation. Because DSI potentiation has been suggested to play a role in persistent limbic hyperexcitability after prolonged seizures in the developing brain, we used these mechanistic insights into activity-dependent DSI potentiation to test whether interference with the induction of DSI potentiation prevents seizure-induced longterm hyperexcitability. The results showed that the in vitro, tetanus-induced DSI potentiation was occluded by previous in vivo feverinduced (febrile) seizures, indicating a common pathway. Accordingly, application of $\mathrm{CB} 1$ receptor antagonists during febrile seizures in vivo blocked the seizure-induced persistent DSI potentiation, abolished the seizure-induced upregulation of CB1 receptors, and prevented the emergence of long-term limbic hyperexcitability. These results reveal a new form of activity-dependent, long-term plasticity of endocannabinoid signaling at perisomatic GABAergic synapses, and demonstrate that blocking the induction of this plasticity abolishes the long-term effects of prolonged febrile seizures in the developing brain.
\end{abstract}

Key words: cannabinoid; inhibition; plasticity; seizure; development; hippocampus

\section{Introduction}

Febrile seizures are the most common form of childhood seizures, affecting 3-5\% of infants (Shinnar and Glauser, 2002). Systematic prospective experimental studies found that prolonged ( $>15 \mathrm{~min}$ ) febrile seizures in the developing rat brain persistently increased hippocampal excitability (Baram et al., 1997; Chen et al., 1999; Dube et al., 2000, 2006), in general agreement with a potential clinical association of prolonged, complex febrile seizures with temporal lobe epilepsy (Annegers et al., 1987; Cendes et al., 1993; French et al., 1993; Hesdorffer and Hauser, 2002). Therefore, uncovering the mechanisms that link prolonged febrile seizures to long-term decreases in seizure threshold remains an important task (Schuchmann et al., 2006).

\footnotetext{
Received Sept. 12, 2006; revised 0ct. 27, 2006; accepted Nov. 22, 2006.

This work was supported by National Institutes of Health Grants NS38580 (I.S.), NS33213 (M.S.), and DA00286 and DA11322 (K.M.), and the Deutsche Forschungsgemeinschaft NE1185/1-1 (A.N.). We thank Dr. D. Piomelli for discussions and Ms. R. Zhu for expert technical assistance.

Correspondence should be addressed to Dr. Ivan Soltesz, Anatomy and Neurobiology, University of California, Irvine, CA 92697-1280. E-mail: isoltesz@uci.edu.

DOI:10.1523/JNEUROSCI.3966-06.2007

Copyright $\odot 2007$ Society for Neuroscience $\quad$ 0270-6474/07/270046-13\$15.00/0
}

After experimental febrile seizures, there is an enhancement of hippocampal GABA release without significant changes in excitatory transmission (Chen et al., 1999) or cell loss (Toth et al., 1998; Bender et al., 2003), but seizure threshold is decreased (Dube et al., 2000). Recently, a solution to this paradox has been suggested involving the long-lasting potentiation of depolarization-induced suppression of inhibition (DSI) by experimental febrile seizures (Chen et al., 2003). DSI is a form of short-term plasticity (Llano et al., 1991; Pitler and Alger, 1992) mediated by CB1 receptors (Kreitzer and Regehr, 2001; Ohno-Shosaku et al., 2001; Wilson et al., 2001; Wilson and Nicoll, 2001), the most numerous G-protein-coupled receptors in the brain (Herkenham et al., 1990; Matsuda et al., 1990). Postsynaptic depolarization and subsequent $\mathrm{Ca}^{2+}$ rise triggers local endocannabinoid production, resulting in inhibition of GABA release from CB1containing terminals. After febrile seizures, DSI amplitude and the number of presynaptic CB1 receptors are increased (Chen et al., 2003). DSI can occur after seizure-like discharges in pyramidal cells (Beau and Alger, 1998), and long-term increase in DSI is expected to facilitate seizures (Chen et al., 2003). Persistent DSI potentiation by febrile seizures is selective, because endocannabinoid-mediated, depolarization-induced suppression of excitation (DSE) (OhnoShosaku et al., 2002) remains unaffected (Chen et al., 2003). 
The cannabinoid system is linked to epilepsy by additional evidence. High-frequency stimulation in slices or kainateinduced seizures in vivo leads to endocannabinoid production and release (Stella et al., 1997; Marsicano et al., 2003; Wettschureck et al., 2006), and CB1 receptors are upregulated after pilocarpine-induced status epilepticus (Wallace et al., 2003). Exogenously applied cannabinoid agonists are acutely anticonvulsant (Corcoran et al., 1973; Chesher and Jackson, 1974; Karler et al., 1974; Wada et al., 1975; Consroe and Wolkin, 1977; Chiu et al., 1979; Wallace et al., 2001, 2002; Shafaroodi et al., 2004; Blair et al., 2006), whereas cannabinoid antagonists are acutely proconvulsant (Wallace et al., 2002; Marsicano et al., 2003; Bernard et al., 2005). Therefore, endocannabinoid signaling significantly modulates seizures acutely (Monory et al., 2006) and, conversely, seizures persistently alter the endocannabinoid system.

Here, we show that induction of DSI potentiation is activitydependent and requires $\mathrm{CB} 1$ receptors. When febrile seizures take place in the presence of CB1 antagonists, long-term enhancement of hippocampal excitability does not develop, indicating that the endocannabinoid system is a potential new target to prevent limbic hyperexcitability after prolonged developmental seizures.

\section{Materials and Methods}

Slice preparation. Horizontal brain slices $(450 \mu \mathrm{m}$; for paired recordings, $350 \mu \mathrm{m}$ ) were prepared as described previously (Chen et al., 1999, 2001; Foldy et al., 2006) from 16- to 18-d-old control or experimental littermate Sprague Dawley rats (Zivic-Miller, Zelienople, PA) 1 week after seizure induction. The animals were anesthetized with halothane, decapitated, and their brains were removed. The slices were incubated at $32^{\circ} \mathrm{C}$ in oxygenated $\left(95 \% \mathrm{O}_{2} / 5 \% \mathrm{CO}_{2}\right)$ artificial CSF [ACSF; containing the following (in mM): $126 \mathrm{NaCl}, 2.5 \mathrm{KCl}, 26 \mathrm{NaHCO}_{3}, 2 \mathrm{CaCl}_{2}, 1.25$ $\mathrm{NaH}_{2} \mathrm{PO}_{4}$, and 10 glucose] in a holding chamber for at least $1 \mathrm{~h}$ before stimulating or recording. For visualized recordings, slices were sectioned and incubated in oxygenated, sucrose-containing ACSF [containing the following (in $\mathrm{mm}$ ): $85 \mathrm{NaCl}, 75$ sucrose, $2.5 \mathrm{KCl}, 25$ glucose, 1.25 $\mathrm{NaH}_{2} \mathrm{PO}_{4}, 4 \mathrm{MgCl}_{2}, 0.5 \mathrm{CaCl}_{2}$, and $\left.24 \mathrm{NaHCO}_{3}\right]$ for $1 \mathrm{~h}$ and then transferred to regular ACSF.

Hippocampal-entorhinal combined slices (Rafiq et al., 1995; Dube et al., 2000) were sectioned $(450 \mu \mathrm{m})$ in cooled, oxygenated high-sucrose ACSF [containing the following (in $\mathrm{mm}$ ): 200 sucrose, $3 \mathrm{KCl}, 1.25 \mathrm{~m}$ $\mathrm{NaH}_{2} \mathrm{PO}_{4}, 26 \mathrm{NaHCO}_{3}, 10$ glucose, $0.9 \mathrm{MgCl}_{2}$, and $2 \mathrm{CaCl}_{2}$ ] along a $12^{\circ}$ inclined transverse plane. Slices were then incubated at $32^{\circ} \mathrm{C}$ in an oxygenated low- $\mathrm{Mg}^{2+}$ ACSF [containing the following (in mM): $130 \mathrm{NaCl}, 3$ $\mathrm{KCl}, 26 \mathrm{NaHCO}_{3}, 2 \mathrm{CaCl}_{2}, 0.5 \mathrm{MgCl}_{2}, 1.25 \mathrm{NaH}_{2} \mathrm{PO}_{4}$, and $10 \mathrm{~mm}$ glucose] for at least $1 \mathrm{~h}$.

Electrophysiology. For blind whole-cell recordings, individual slices were transferred to an interface-type recording chamber perfused with oxygenated ACSF at $35^{\circ} \mathrm{C}$, which, depending on the experiment, contained some of the following drugs: $10 \mu \mathrm{M} \mathrm{D}-2$-amino-5phosphovaleric acid (APV), $10 \quad \mu \mathrm{M}$ 1,2,3,4-tetrahydro-6-nitro-2,3-dioxo-benzo [f] quinoxaline-7-sulfonamide (NBQX), $5 \mu \mathrm{M}$ 6-cyano-7-nitroquinoxaline-2,3-dione (CNQX), $200 \mu \mathrm{M}$ LY341495, $10 \mu \mathrm{M}$ bicuculline methochloride, or $1 \mu \mathrm{M}$ SR141716A (SR). Tetanic stimulation (5 trains of 1 or $10 \mathrm{~s}$ stimuli at $100 \mathrm{~Hz}$, with a stimulus width of $20 \mu$ s, and intensity of $2 \mathrm{~mA}$, delivered at $30 \mathrm{~s}$ intervals) was applied through a bipolar $90 \mu \mathrm{m}$ tungsten electrode placed in the stratum radiatum at the CA1-CA3 border. Sham control slices were handled the same way, but the stimulating current was not delivered. The slices were returned to the incubating chamber for washing in control ACSF, and kept for a minimum of $1 \mathrm{~h}$ before recording. Recordings were obtained using an Axopatch 200A amplifier (Molecular Devices, Union City, CA). Spontaneous IPSCs (sIPSCs) were recorded in ACSF containing APV, NBQX (or in some experiments, CNQX), and $5 \mu \mathrm{M}$ carbachol. To evoke EPSCs or perisomatic IPSCs (latency, $<3.1 \mathrm{~ms}$ ), constant-current stimuli $(20 \mu \mathrm{s})$ were applied through the tungsten electrode. The placement and distance of the recording and stimulating electrodes were kept constant as described previously (Chen et al., 1999). The recorded cells were from the middle third of the CA1 region (i.e., about half-way between the CA3 and the subiculum). Pipette solutions for DSI experiments consisted of the following (in mM): $140 \mathrm{CsCl}, 2 \mathrm{MgCl}_{2}, 10 \mathrm{HEPES}, 3$ QX314, 0.2 EGTA, 1 MgATP, and $0.2 \mathrm{Na}_{2} \mathrm{GTP}$ (for eIPSCs, no EGTA, ATP, or GTP was included in the pipette; for DSE, $\mathrm{CsCl}$ was replaced with $\mathrm{K}$ gluconate). Note that these pipette solutions were identical to those used previously to obtain data on the effects of febrile seizures on endocannabinoid signaling (Chen et al., 2003). The depolarizing pulse used to evoke DSI was a 100 or $500 \mathrm{~ms}$ step to $0 \mathrm{mV}$ from a holding potential of $-60 \mathrm{mV}$. For eEPSCs, recordings were in ACSF containing bicuculline, and DSE was induced by a depolarizing step of $10 \mathrm{~s}$ duration.

For extracellular recordings in hippocampal-entorhinal combined slices (Rafiq et al., 1995; Dube et al., 2000) performed in low- $\mathrm{Mg}^{2+}$ ACSF, recording pipettes were filled with normal ACSF and placed in the CA1 pyramidal cell layer, and the tungsten stimulating electrode was positioned in the CA1 stratum radiatum. The stimulation protocol consisted of a $2 \mathrm{~s}, 60 \mathrm{~Hz}$ train of stimuli, and stimulus intensities were adjusted to four times the minimal intensity required to evoke a population spike of $0.5 \mathrm{mV}$ in amplitude, usually 3 to $4 \mathrm{~mA}$. Six stimulating trains with a $10 \mathrm{~min}$ interval were applied to each slice, unless sustained epileptiform activity developed. Recording was terminated if sustained seizure-like activity lasted for $>35 \mathrm{~min}$. After the recording of the responses to the stimulating trains, the recording pipette was placed at four additional recording sites in CA1, to ascertain the network-wide nature of the recorded population activity. Duration of epileptiform discharges was determined by considering episodes with repetitive spikes, with amplitudes $>2$ times the background and frequency $>1 \mathrm{~Hz}$, lasting for $>3$ s (Dube et al., 2000).

For visualized paired whole-cell recordings, slices were transferred to a submerged-type recording chamber perfused with oxygenated ACSF at $33^{\circ} \mathrm{C}$. Slices were visualized with an upright microscope (BX-50; Olympus, Tokyo, Japan) with infrared differential interference contrast optics. Whole-cell recordings were obtained from interneurons with patch pipettes (3-5 M $\Omega$ ) filled with internal solution containing the following (in mM): 126 K-gluconate, $4 \mathrm{KCl}, 10$ HEPES, 4 MgATP, $0.3 \mathrm{Na}_{2} \mathrm{GTP}, 10$ phosphocreatine, and $0.2 \%$ biocytin, $\mathrm{pH} 7.2,270-290 \mathrm{mOsm}$. The interneurons were all DSI-sensitive [hence CB1 receptor expressing, cholecystokinin (CCK) positive] interneurons that evoked fast unitary IPSCs (Foldy et al., 2006). Pyramidal cells were recorded with internal solution containing the following (in $\mathrm{mm}$ ): $40 \mathrm{KCl}, 90 \mathrm{~K}$-gluconate, $1.8 \mathrm{NaCl}, 1.7$ $\mathrm{MgCl}_{2}, 3.5 \mathrm{KCl}, 0.05$ EGTA, 10 HEPES, $2 \mathrm{Mg}$-ATP, $0.4 \mathrm{Na}_{2}$-GTP, and 10 phosphocreatine, $\mathrm{pH} 7.2,270-290 \mathrm{mOsm}$. DSI was elicited with a $500 \mathrm{~ms}$ depolarizing pulse to $0 \mathrm{mV}$ from a holding potential of $-70 \mathrm{mV}$. Recordings were made using MultiClamp 700A and MultiClamp 700B amplifiers (Molecular Devices). Immunoreactivity for CCK and parvalbumin was determined as described by Foldy et al. (2006). For CCK, we used a mouse monoclonal antibody [ $\mathrm{mAb} 9303$; diluted 1:1000; generously provided by the Antibody/Radioimmunoassay Core of the CURE/Digestive Diseases Research Center (University of California, Los Angeles, Los Angeles, CA), and National Institutes of Health Grant DK41301]. For parvalbumin, a rabbit polyclonal antibody (PV-28; Swant, Bellinzona, Switzlerland) was used. For further details, see Foldy et al. (2006).

All drugs were obtained from Tocris, (Ellisville, MO) except for carbachol, which was obtained from Sigma (St. Louis, MO), and SR141716A, which was obtained from the National Institute of Mental Health Chemical Synthesis Program at either SRI International (Palo Alto, CA) or Research Triangle Institute (Research Triangle Park, NC).

Hyperthermia-induced experimental febrile seizures. The hyperthermiainduced experimental prolonged febrile seizure paradigm has been described previously (Baram et al., 1997; Dube et al., 2000). Briefly, on postnatal day 10 (P10), the core temperature of pups was raised using a regulated stream of moderately heated air. Rectal temperatures were measured at baseline, at 2 min intervals, and at the onset of hyperthermic seizures, which occur in virtually all rats. Hyperthermia (defined as core temperature $>39.5^{\circ} \mathrm{C}$ ) was maintained for $30 \mathrm{~min}$, aiming for a core temperature of $41-42^{\circ} \mathrm{C}$, and the presence and duration of seizures for each pup were noted at 2 min intervals. The number of seizure sessions was defined as the number of 2 min intervals in which the rat was seizing. 
After the hyperthermia period, rats were placed on a cool surface, monitored for $15 \mathrm{~min}$, and then returned to home cages. For the animals that received an injection of the CB1 receptor antagonist SR141716A systemically, SR141716A was first dissolved in alcohol and then normal saline was added (alcohol to saline ratio, 1:20). The total volume injected intraperitoneally to each pup was $70 \mu$ l. The composition and volume of the control vehicle solution were the same as in the case of the SR141716Acontaining solution, but no SR141716A was added. The injection was administered $1 \mathrm{~h}$ before hyperthermia was performed (SR141716A dose was $10 \mathrm{mg} / \mathrm{kg}$ or $1 \mathrm{mg} / \mathrm{kg}$, as specified in the text).

Western blots. Hippocampi from either controls or animals with hypothermia-induced seizures (HT), which had been preinjected with either SR or vehicle, were prepared for Western blots as described previously (Chen et al., 2003). Briefly, hippocampi were homogenized in fivefold (volume/weight) excess buffer containing $25 \mathrm{~mm}$ HEPES, $10 \mathrm{~mm}$ EDTA, $6 \mathrm{~mm} \mathrm{MgCl}, 100 \mu \mathrm{M}$ PMSF, $10 \mu \mathrm{M}$ leupeptin, $100 \mu \mathrm{M}$ benzamidine, and $10 \mu \mathrm{M}$ aprotenin, $\mathrm{pH}$ 7.4. Homogenates were centrifuged for 5 min at $1000 \times g$, the supernatants saved, and the pellets were rehomogenized in buffer and centrifuged as above. The protein concentrations of the combined supernatants were determined using a Bio-Rad (Hercules, CA) assay. Protein $(75 \mu \mathrm{g})$ from each animal were separated by SDSPAGE and transferred to nitrocellulose. Western blot analysis was performed blind with respect to experimental treatment using an antibody raised against the last 15 amino acids of rat $\mathrm{CB} 1$ receptor fused to glutathione S-transferase (CB1 L15; 1:250). The antibody was purified and specificity verified as described previously (Bodor et al., 2005). The top portion of the blot containing the higher molecular weight proteins was probed with antibodies (Sigma) to neurofilament polypeptides with apparent molecular weight of $160 \mathrm{kDa}$ and $200 \mathrm{kDa}$. The CB1 band density was normalized to the neurofilament band density to control for small variations in protein loading. Immunoreactivity was visualized using HRP-conjugated secondary antibodies and $\mathrm{DAB} / \mathrm{Ni}^{2+}$ staining (Vector Laboratories, Burlingame, CA). The intensities of the immunoreactive bands were quantified using NIH Image software (http://rsb.info. nih.gov/nih-image/).

EEG recordings. For implantation of hippocampal depth electrodes (single twisted-wire electrode; Plastics One, Roanoke, VA) rats were anesthetized with ketamine/xylazine and placed in a stereotaxic frame. The scalp was incised, and a small hole was drilled into the right parietal bone. The electrode was placed into the brain stereotaxically and fixed in place with cyanoacrylate adhesive, steel screws, and dental cement. The wound was closed around the electrode with sutures and the animals were placed on a heating pad for recovery and returned to their cage after awakening. For adult rats ( 6 weeks after HT), the coordinates of the electrodes were as follows: anteroposterior (AP), $3.3 \mathrm{~mm}$ from bregma, lateral (L), $2.2 \mathrm{~mm}$; ventral (V), $3.0 \mathrm{~mm}$. For juvenile rats (P8), the coordinates were as follows: AP, $2.0 \mathrm{~mm}$ from bregma; $\mathrm{L}, 2.0 \mathrm{~mm} ; \mathrm{V}, 2.5$ $\mathrm{mm}$ vertical. Implantation was performed 2 to $3 \mathrm{~d}$ before EEG recording. Electrode position was subsequently verified from histology. On the day of the recording, animals were placed into the recording chamber and the implanted electrodes were attached to a flexible cable. The signal was amplified at a gain of 1000 on a Brownlee Precision (Santa Clara, CA) 210A amplifier. Baseline EEG activity was recorded for $10 \mathrm{~min}$, and then a single dose of kainate $(5 \mathrm{mg} / \mathrm{kg}$, dissolved in saline to $5 \mathrm{mg} / \mathrm{ml}$ ) was given intraperitoneally. EEGs were then recorded for $60 \mathrm{~min}$ continuously. The criteria for an EEG seizure were the following: (1) the presence of repetitive spike and sharp-wave discharges, with a frequency $>1 \mathrm{~Hz}$, (2) amplitude of activity $>2$ times baseline activity, and (3) a duration of $>5$ s. A seizure was considered to terminate when this activity stopped for $>3 \mathrm{~s}$.

Data analysis. Recordings were filtered at 4 or $5 \mathrm{kHz}$ using a Bessel filter and digitized at $10 \mathrm{kHz}$ with a Digidata $1322 \mathrm{~A}$ analog-digital interface (Molecular Devices). Statistical analyses were performed with SigmaPlot or SPSS software (SPSS, Chicago, IL) using a $t$ test (for data containing two groups) or an $f$ test (for more than two groups), or the nonparametric Kruskal-Wallis test (for the hippocampal-entorhinal cortex combined slice data) with a level of significance of $p<0.05$. Data are presented as mean \pm SEM, and $n$ is the number of recorded cells, slices, or animals.

\section{Results}

Strategy for the prevention of the long-term consequences of febrile seizures through modulating plasticity of endocannabinoid signaling

How do hyperthermia-induced experimental febrile seizures (HTs) lead to persistent potentiation of endocannabinoid signaling at perisomatic GABAergic synapses in the hippocampus (Chen et al., 2003), and does prevention of DSI potentiation block the HT-induced long-term enhancement of limbic network excitability (Dube et al., 2000)? To answer these important questions, a multistep strategy was implemented. First, to circumvent difficulties associated with in vivo testing of drug effects during HT induction, we identified an in vitro paradigm of DSI potentiation. Second, using blockers for various neurotransmitters and neuromodulators in the in vitro paradigm, we delineated key steps involved in the induction of DSI potentiation. Third, we determined that the receptor blockers that were effective in the in vitro paradigm prevented the in vivo, HT-induced DSI potentiation. Finally, we showed that approaches effective at blocking DSI potentiation also prevented the long-term enhancement of limbic network hyperexcitability after HT in vivo.

\section{Increased neuronal activity results in potentiation of DSI in control slices}

We reasoned that if in vivo febrile seizures enhance DSI in CA1 pyramidal cells through increased neuronal activity alone, then electrical stimulation of afferent fibers in acute in vitro slices may be able to enhance DSI. However, such an effect has not been described previously. In fact, there is evidence that certain stimulation paradigms can depress inhibitory transmission from specific populations of CB1-expressing fibers [resulting in inhibitory long-term depression (iLTD)] (Chevaleyre and Castillo, 2003, 2004). Therefore, we tested whether increased neuronal activity in hippocampal slices results in potentiation of DSI in CA1 pyramidal cells.

Tetanic stimulation $(5 \times 10 \mathrm{~s}$ at $100 \mathrm{~Hz})$ in the CA1 stratum radiatum layer in acute hippocampal slices from control animals that did not experience previous febrile seizures resulted in a significant potentiation of DSI (Fig. $1 A, B$ ) (age, P18; tetanization was performed in control ACSF, followed by at least $1 \mathrm{~h}$ incubation in control ACSF before DSI was measured). Specifically, compared with sham-stimulated controls, tetanic stimulation significantly increased the peak amplitude of DSI of sIPSCs (recorded in the presence of the ionotropic glutamate receptor blockers $5 \mu \mathrm{M}$ CNQX, $10 \mu \mathrm{M} \mathrm{APV}$, and the muscarinic agonist 5 $\mu \mathrm{M}$ carbachol to enhance sIPSC frequency) (Martin et al., 2001; Kim et al., 2002) (Fig. 1A,B,D, left pair of bar graphs) [DSI amplitude, expressed as percent decrease in sIPSC charge transfer after the depolarizing pulse, with respect to the prepulse control period, in cells from sham-stimulated slices ("sham-tet"), $18.9 \pm$ $4.0 \%, n=11$ cells; DSI in cells from tetanically stimulated slices (“tetanus"), $37.8 \pm 4.2 \%, n=10$ ].

In addition to enhancing the peak DSI, tetanization also significantly prolonged the duration of DSI (Fig. $1 A, B$ ) (DSI single exponential decay time constants in cells from sham-tetanized slices, $\tau_{\text {decay }}=2.06 \pm 0.32 \mathrm{~s}$; tetanized, $\tau_{\text {decay }}=9.19 \pm 2.17 \mathrm{~s}$ ). Therefore, tetanization of afferents in acute slices from control animals was able to reproduce the two major, characteristic changes in DSI that were reported to take place after in vivo febrile seizures, namely, the significant potentiation of DSI peak amplitude and the prolongation of DSI decay.

In vitro, tetanus-induced DSI potentiation was long-lasting, persisting as long as slices could be kept viable (up to $5 \mathrm{~h}$ ), and the DSI potentiation was evident in virtually all CA1 pyramidal cells. 


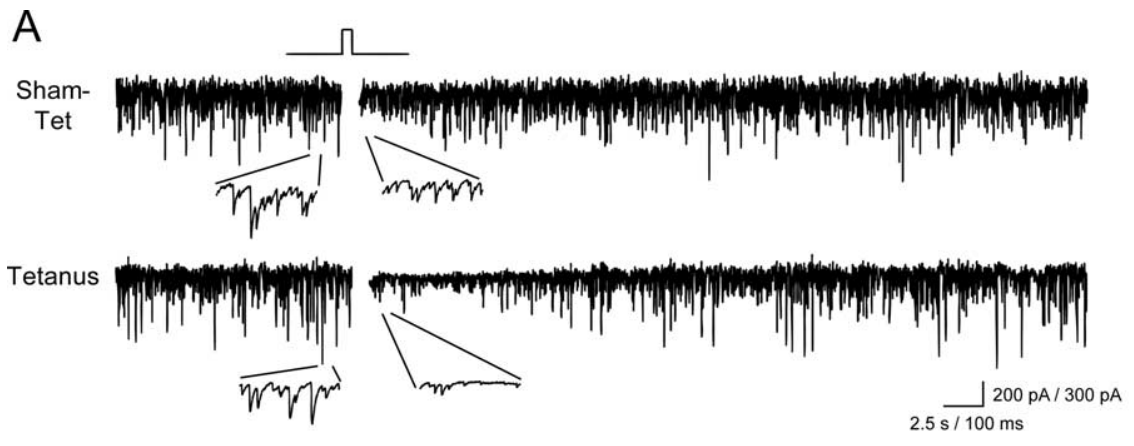

B
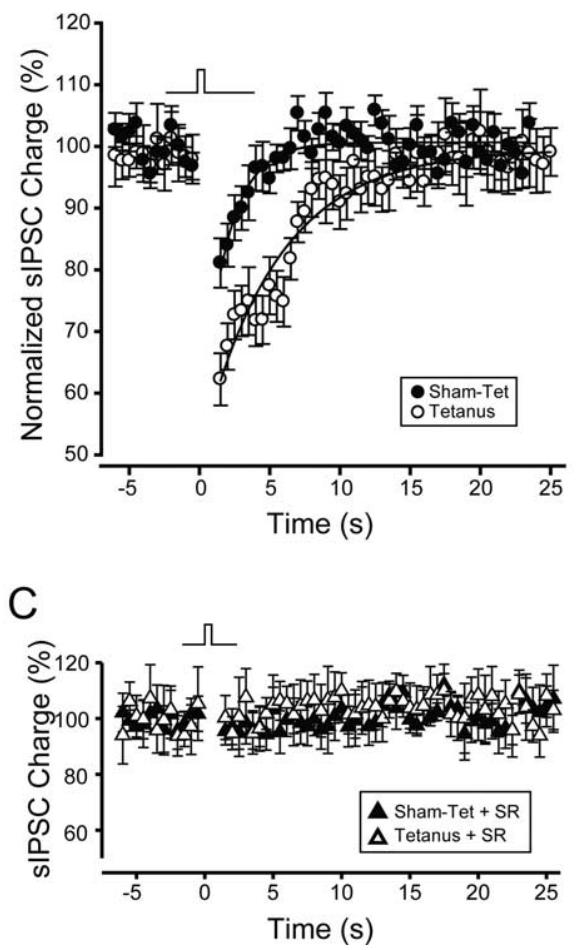

D

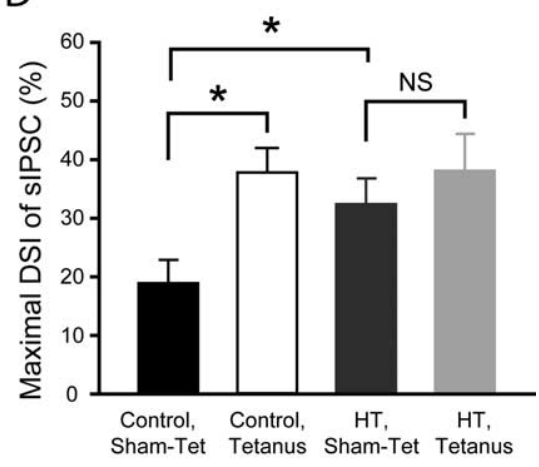

$\mathrm{E}$

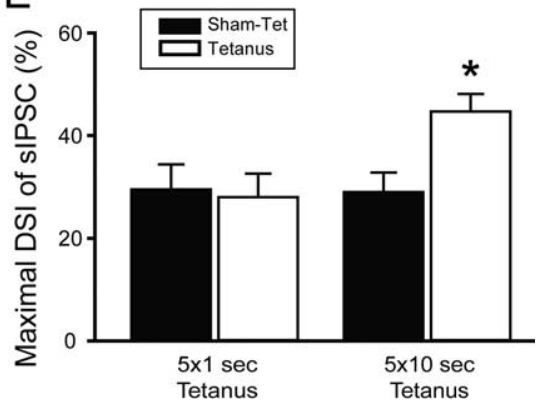

Figure 1. Increased neuronal activity leads to potentiation of DSI. $\boldsymbol{A}, \boldsymbol{B}$, Strong $(5 \times 10 \mathrm{~s}$ at $100 \mathrm{~Hz})$ tetanic stimulation in the stratum radiatum (including the Schaffer collateral pathway) in slices from control animals increased DSI amplitude and prolonged the DSI decay in CA1 pyramidal cells. Example traces are shown in $\boldsymbol{A}$; summary data are shown in $\boldsymbol{B}$ (based on 3 DSI episodes per cell separated by $1 \mathrm{~min}$ ). Square waves above traces and summary graph indicate time and duration of depolarization. $C$, Even after tetanic stimulation, DSI is completely blocked in the presence of the CB1 receptor antagonist SR141716 (1 $\mu \mathrm{M})$. D, Tetanic stimulation and hyperthermic seizures (performed 1 week before recording), both potentiate DSI to a similar extent. Additionally, tetanic stimulation cannot further potentiate DSI in slices from HT animals, suggesting a common mechanism of potentiation. $\boldsymbol{E}$, The potentiation of DSI requires a strong tetanic stimulation, as a weaker protocol $(5 \times 1 \mathrm{~s}$ at $100 \mathrm{~Hz})$ does not increase DSI. For all experiments in this figure, DSI was induced by a $500 \mathrm{~ms}$ depolarization to $0 \mathrm{mV}$ and recorded in the presence of carbachol and ionotropic glutamate receptor blockers (see Materials and Methods). Recordings were made at least $1 \mathrm{~h}$ after sham stimulation (sham-tet) or tetanus (tetanus). In this and following figures, asterisks indicate significant differences $(p<0.05)$.

The potentiated DSI after the tetanization, similar to DSI in shamstimulated control slices, could be abolished with $1 \mu \mathrm{M}$ of the CB1 antagonist SR141716A [rimonabant (Rinaldi-Carmona et al., 1994)] (Fig. 1C) (DSI in the presence of SR141716A, in cells from sham-stimulated slices, $4.5 \pm 5.0 \%, n=5$; in tetanized slices, $-0.4 \pm 7.9 \%, n=5$ ), indicating that the potentiated DSI is mediated by $\mathrm{CB} 1$ receptors. Furthermore, the DSI potentiation took place without significant changes in the baseline sIPSC charge transfer (measured before the depolarizing steps used to evoke DSI; cells from sham-stimulated slices, $64.7 \pm 6.9 \mathrm{pA}^{\star} \mathrm{ms}$; in tetanized slices, $63.8 \pm 6.1 \mathrm{pA}^{\star} \mathrm{ms}$ ). To our knowledge, this is the first demonstration of DSI potentiation induced by increased neuronal activity in vitro.
Occlusion of tetanus-induced DSI potentiation by previous febrile seizures The data presented above showed that seizure-like afferent activity in vitro could potentiate DSI amplitude and duration, similar to what takes place after in vivo febrile seizures (Chen et al., 2003). The similarity between in vitro tetanus- and in vivo HT-induced DSI potentiation was tested further by determining whether the in vivo febrile seizures could occlude DSI potentiation caused by in vitro tetanization. In contrast to the potentiation of DSI of sIPSCs after tetanization of slices from control animals (Fig. 1D, left pair of bar graphs), tetanization in slices from agematched (P18), littermate animals that had experienced HT 1 week before the recording session failed to enhance DSI, compared with sham-stimulated slices from HT animals (Fig. $1 D$, right pair of bar graphs). Specifically, in slices from animals that had febrile seizures, the peak amplitude of DSI was already as large as in tetanized slices from control animals, and could not be increased further with tetanization (DSI amplitude, in cells from shamstimulated control slices from HT animals, $32.4 \pm 4.4 \%, n=10$; in cells from tetanized slices from HT animals, $38.1 \pm$ $6.3 \%, n=5)$. Therefore, previous in vivo HT occluded the DSI potentiating effects of in vitro tetanization, suggesting a common underlying mechanism.

\section{Requirement for strongly enhanced afferent activity for DSI potentiation} How sensitive is the DSI amplitude to changes in neuronal activity? Can smaller increases in afferent inputs potentiate DSI, or does long-term DSI potentiation take place only after seizurelike events? To answer these questions, sIPSCs were recorded in sham-control slices, and in slices that were stimulated with either weaker or stronger tetanus (stimulation was in control ACSF, the recordings in $10 \mu \mathrm{M}$ NBQX, $10 \mu \mathrm{M}$ APV and $5 \mu \mathrm{M}$ carbachol). As in the previous experiments, the stronger $(5 \times 10 \mathrm{~s}$ at $100 \mathrm{~Hz}$ ) tetanus caused a significant potentiation of DSI (Fig. 1E) (DSI in cells from sham-stimulated slices, $29.0 \pm 3.8 \%, n=11$; from tetanized slices, $44.7 \pm 3.4 \%$, $n=11)$. In contrast, a weaker $(5 \times 1 \mathrm{~s}$ at $100 \mathrm{~Hz})$ tetanus did not result in increased DSI (Fig. $1 E$ ) (DSI in cells from shamstimulated slices, $29.5 \pm 4.9 \%, n=10$; in tetanized slices, $27.9 \pm 4.6 \%, n=10$ ). Therefore, DSI potentiation requires strongly enhanced inputs, such as those that may take place with seizure-like network hyperactivity.

\section{Robustness of tetanus-induced DSI potentiation}

The similarity of the effects on DSI amplitude and duration after tetanization of afferent fibers in vitro and HT in vivo suggested 
that the activity-induced potentiation of DSI is a robust phenomenon that may take place under a variety of experimental conditions. Therefore, additional experiments were performed to test the robustness of DSI potentiation. Tetanic stimulation, similar to its enhancement of the DSI of sIPSCs, also increased the DSI of multifiber, electrical stimulation evoked IPSCs (eIPSCs) (Fig. 2A,B) (DSI in cells from sham-tetanized slices, $15.1 \pm 2.3 \%, n=$ 11 ; from tetanized slices, $29.6 \pm 3.2 \%, n=$ 11). Because these experiments involving eIPSCs were conducted in the absence of carbachol, these results also indicated that the tetanus-induced DSI potentiation could be observed both in the presence and absence of cholinergic stimulation. The tetanus-induced DSI potentiation took place without a significant change in eIPSC amplitudes (Fig. 2C) (for description of positioning of stimulation electrodes, see Materials and Methods). The lack of a change in eIPSC amplitude after tetanization was in agreement with the lack of a tetanus-induced alteration in sIPSC charge transfer (see above), further indicating that no significant iLTD (Chevaleyre and Castillo, 2003, 2004) took place under these conditions (for paired recording data, see below).

Tetanus-induced DSI potentiation was significant not only when assessed with $500 \mathrm{~ms}$ depolarizing pulses to $0 \mathrm{mV}$, because the DSI enhancing effect of tetanization could also be observed with $100 \mathrm{~ms}$ depolarizing pulses (Fig. 2D) (DSI, with a $100 \mathrm{~ms}$ depolarizing pulse, in cells from sham-stimulated slices, $11.5 \pm 3.0 \%, n=$ 10; in tetanized slices, $20.1 \pm 2.7 \%, n=10$; for data on DSI potentiation measured with $500 \mathrm{~ms}$ depolarizing pulse, see above).

In addition, DSI potentiation after tetanization of Schaffer collaterals in vitro had a rapid onset, as DSI of eIPSCs in pyramidal cells was already significantly potentiated $15 \mathrm{~min}$ after tetanization (Fig. $2 A$, bottom row, $B$, open triangles) (mean time after tetanus, $15.5 \pm 1.1 \mathrm{~min}$; range, 10-20 min; DSI in cells from slices $15 \mathrm{~min}$ after tetanus, $31.7 \pm 4.8 \%, n=8$ ). These data indicate the robustness, as well as the rapid onset, of the DSI potentiation resulting from a period of strongly increased afferent activity to CA1.

Tetanic stimulation of Schaffer collaterals enhances tonic inhibition of GABA release by $\mathrm{CB} 1$ receptors

The above data show that in vitro stimulation of Schaffer collaterals, similar to in vivo febrile seizures, results in increases in the amplitude and duration of DSI. Febrile seizures, in addition to potentiating DSI amplitude and duration, have been shown to
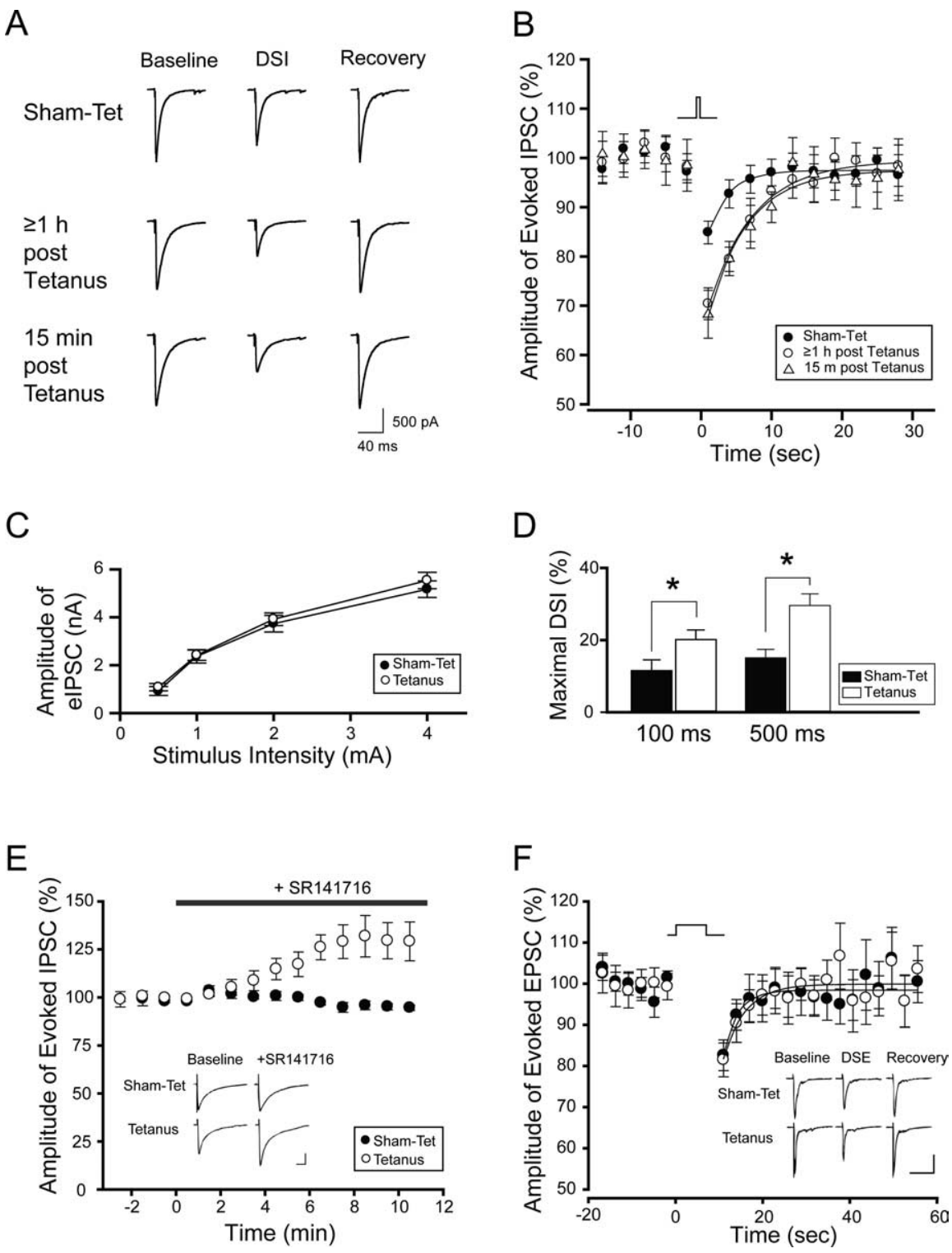

Figure 2. Tetanic stimulation rapidly potentiates DSI of elPSCS, increases the sensitivity of elPSCs to CB1 receptor antagonists/ inverse agonists, and does not affect the magnitude of DSE. $\boldsymbol{A}, \boldsymbol{B}$, Tetanic stimulation potentiates DSI of elPSCs, and the full effect of potentiation is present within $15 \mathrm{~min}$ after stimulation. Representative traces are shown in $\boldsymbol{A}$, summary data are shown in $\boldsymbol{B}$. Square wave in $\boldsymbol{B}$ represents time and duration of depolarizing pulse. IPSCs were evoked with stimulation at the border of stratum radiatum and stratum pyramidale. DSI was induced by a $500 \mathrm{~ms}$ depolarization to $0 \mathrm{mV}$ and recorded in the presence of ionotropic glutamate receptor blockers, but without carbachol. C, In agreement with the lack of change in sIPSC charge transfer after tetanus, the amplitude of evoked IPSCs is not changed by tetanic stimulation for any stimulation intensity tested (note that the stimulating and recording electrodes were carefully positioned in a reproducible manner) (Chen et al., 1999, 2001) (see Materials and Methods). D, Tetanic stimulation potentiates DSI evoked by either 100 or $500 \mathrm{~ms}$ depolarizing pulses. $\boldsymbol{E}$, Tetanic stimulation causes eIPSCs to become sensitive to the CB1 antagonist SR141716. The inset shows representative traces. Calibration: 50 ms, 100 pA. Symbols refer to $\boldsymbol{E}$ and $\boldsymbol{F}$. $\boldsymbol{F}$, The potentiation of endocannabinoid signaling caused by tetanic stimulation is specific to inhibitory synapses, as the amplitude and decay of DSE are not affected by tetanus. DSE was evoked by a 10 s depolarizing pulse and was recorded in the presence of bicuculline $(10 \mu \mathrm{m})$. The square wave represents the time and duration of the depolarizing pulse. The inset shows representative traces. Calibration: $80 \mathrm{~ms}, 400 \mathrm{pA}$.

increase the $\mathrm{CB} 1$-dependent tonic inhibition of GABA release (Chen et al., 2003). Therefore, we performed experiments to determine whether in vitro tetanization enhances the tonic inhibition of GABA release by CB1 receptors. As shown in Figure 2E, perfusion of the $\mathrm{CB} 1$ antagonist (and inverse agonist) SR141716A (Rinaldi-Carmona et al., 1994; Bouaboula et al., 1997; Landsman et al., 1997; Pan et al., 1998; Vasquez and Lewis, 1999; Hurst et al., 2002) in CA1 pyramidal cells in nontetanized 
slices (from control animals) did not cause a significant change in the peak amplitude of eIPSCs, in agreement with previous reports (Hoffman and Lupica, 2000; Wilson and Nicoll, 2001; Chen et al., 2003). However, in cells from tetanized slices (from control animals), perfusion of SR141716A resulted in a significant increase in eIPSC amplitude (Fig. 2E) (recordings made $>1 \mathrm{~h}$ after tetanus; peak eIPSC amplitude in the presence of SR141716A, with respect to pre-SR141716A baseline, in cells from shamstimulated control slices, $95.5 \pm 1.8 \%, n=4$; from tetanized slices, $129.1 \pm 9.1 \%, n=5)$. The potentiating effect of SR141716A on eIPSC peak amplitudes after tetanization was remarkably similar to its effect on eIPSCs after in vivo HT [Chen et al. (2003), their Fig. $3 A, B]$.

\section{Tetanization does not change DSE}

The effects of febrile seizures on cannabinoid signaling have been shown to be specific to GABAergic synapses, as HT caused DSI potentiation without changes in DSE (Chen et al., 2003). As shown in Figure $2 \mathrm{~F}$, the potentiation in CB1-mediated inhibition of transmitter release after tetanic stimulation in vitro was also selective to DSI, because it failed to cause any significant alteration in DSE (DSE in cells from sham-tetanized slices, $17.4 \pm$ $3.7 \%, n=6$; tetanized, $18.5 \pm 4.1 \%, n=6$; note that the depolarizing pulse needs to be longer for evoking DSE, $10 \mathrm{~s}$ ) (OhnoShosaku et al., 2002; Chen et al., 2003, see also Straiker and Mackie, 2005). Together, the experiments presented so far indicate that the in vitro tetanus-induced DSI potentiation replicates several key features of DSI potentiation observed after in vivo febrile seizures, including the selectivity of the modulation of DSI but not DSE.

\section{Tetanus-induced DSI potentiation occurs at synapses between endocannabinoid-sensitive interneurons and pyramidal cells}

The data presented above show that tetanic stimulation significantly enhances DSI of both sIPSCs and eIPSCs. Because sIPSCs and eIPSCs originate from a mixed population of GABAergic fibers (containing both CB1-expressing, cannabinoid-sensitive and CB1-negative, cannabinoid-insensitive axons), it is possible that tetanic stimulation increased the relative contribution of CB1-expressing axons to the recorded events, leading to an apparent potentiation of DSI, without an actual increase in endocannabinoid signaling at axons between CB1-containing terminals and pyramidal cells. To investigate this question, we performed paired whole-cell patch-clamp recordings between DSI sensitive presynaptic interneurons evoking fast unitary IPSCs (uIPSCs; $10-90 \%$ rise-times of uIPSCs, $0.62 \pm 0.05 \mathrm{~ms} ; n=$ 14) and their pyramidal cell postsynaptic targets. The DSI sensitivity identified these presynaptic cells as CB1 receptor expressing interneurons, and the fast uIPSC rise times indicated that they were most likely basket cells (Katona et al., 1999; Wilson et al., 2001; Foldy et al., 2006; Glickfeld and Scanziani, 2006). Synaptically connected pairs were obtained from slices that were either sham-stimulated or tetanized before the beginning of the recording session (the time between the stimulation and the establishment of the paired recordings was $27.7 \pm 2.4 \mathrm{~min}$; the extracellular medium was control ACSF during both the tetanization and the paired recordings).

As illustrated in Figure 3, tetanization significantly potentiated DSI of the UIPSCs recorded between the interneurons and the CA1 pyramidal cells. Specifically, DSI in sham-stimulated control slices was $55.7 \pm 11.7 \%(n=8$ pairs $)$, and it was significantly increased in pairs recorded from slices that were tetanically stimulated (87.3 \pm
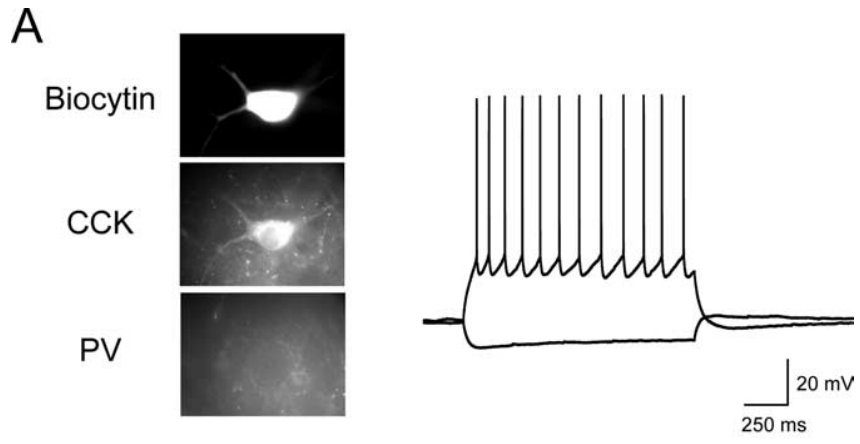

B

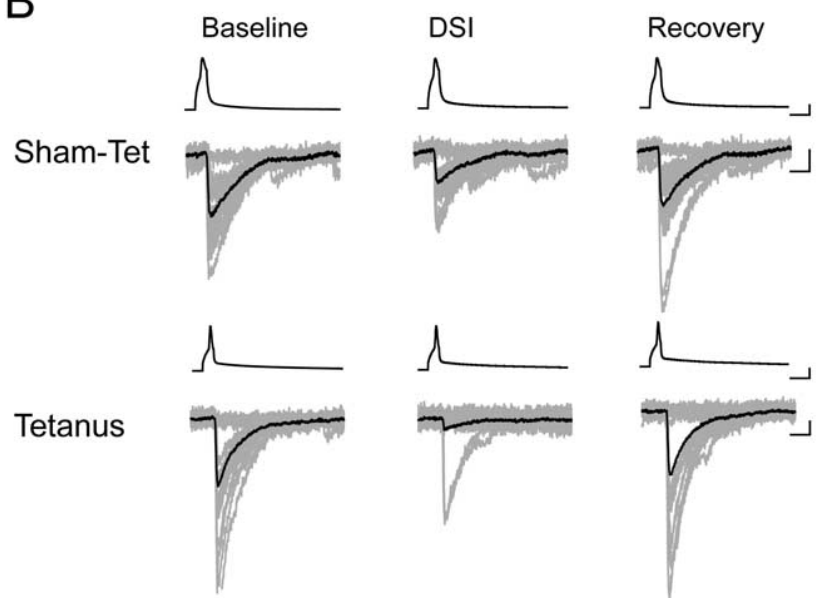

Figure 3. Paired recordings show that DSI at CB1 expressing interneuron to pyramidal cell synapses is potentiated by tetanic stimulation. $A$, Biocytin fill from a representative interneuron demonstrates the presence of CCK immunostaining and the absence of PV immunostaining (all cells that were successfully recovered were CCK positive and PV negative; $n=9$ of 14 recordings). Traces on the right demonstrate the characteristic firing pattern and hyperpolarizing response of CCK-positive interneurons after the injection of $+140 \mathrm{pA}$ and $-80 \mathrm{pA}$ current pulses. These cells are similar to those examined and illustrated by Foldy et al. (2006). B, DSI of ulPSCs is significantly increased by tetanic stimulation. Top traces show action potentials evoked in the presynaptic basket cell; bottom traces show 20 individual uIPSCs in the postsynaptic pyramidal cell from each time point (gray) as well the averaged uIPSC (black). The time points were as follows, with the zero time point being the start of the depolarizing pulse: baseline or pre-DSI period, -2 s to $0 \mathrm{~s} ; \mathrm{DSI}, 0.5$ to $2.5 \mathrm{~s}$; recovery, 4 to $6 \mathrm{~s}$. The illustrated traces are consecutive responses obtained by triggering action potentials in the presynaptic interneuron at $10 \mathrm{~Hz}$; as described previously in detail (Foldy et al. 2006), this stimulation frequency resulted in stable responses over time and also allowed us to obtain a sufficiently large number of events for reliable analysis. Calibration: $\boldsymbol{B}$, presynaptic, 25 $\mathrm{mV}, 5 \mathrm{~ms}$; postsynaptic, $25 \mathrm{pA}, 5 \mathrm{~ms}$. All experiments in this figure were performed in control ACSF and DSI was evoked by $500 \mathrm{~ms}$ pulses.

$4.1 \% ; n=6)$. Therefore, data from these paired-recording experiments confirmed the results from the above-described sIPSC and eIPSC DSI experiments indicating that tetanization potentiates DSI. In addition, in agreement with the lack of iLTD of the sIPSCs and perisomatic eIPSCs (Fig. 2C), the amplitude of the uIPSCs in these paired recordings was also not decreased after the tetanic stimulation (if anything, there was a nonsignificant trend for increased uIPSC amplitude after tetanization; uIPSC amplitudes, including failures, in pairs from sham-stimulated slices, $70.1 \pm 13.9 \mathrm{pA}$; in tetanized slices, $108.0 \pm 53.0 \mathrm{pA}$ ).

Mechanisms of induction of DSI potentiation after tetanic stimulation in vitro: dual requirement for non-NMDA ionotropic and metabotropic glutamate receptors

Based on the similarities established by the previous experiments between the DSI potentiation after tetanic stimulation in vitro 
and DSI potentiation after HT in vivo, we took advantage of the accessibility of the in vitro tetanization paradigm to pharmacological manipulations to investigate the mechanisms underlying the induction phase of DSI potentiation. In contrast to the potentiation of DSI when tetanization was performed in ACSF (as in all previous experiments), tetanization in the presence of $10 \mu \mathrm{M}$ NBQX did not increase DSI (Fig. 4A, NBQX) (DSI of eIPSCs after sham-stimulation in NBQX, $19.9 \pm 2.6 \%, n=9$; after tetanization in NBQX, $16.3 \pm 3.2 \%, n=10$; note that in these and subsequent experiments on induction mechanisms, the slices were incubated in control ACSF during the $>1 \mathrm{~h}$ time between the tetanization and the beginning of patch-clamp recording for the DSI assessment, to wash out the particular drug that was being tested for its effect on induction). Therefore, AMPA/kainate glutamate receptors are critical for the induction of DSI potentiation. In contrast, significant DSI potentiation took place when tetanization was performed in the presence of $10 \mu \mathrm{M} \mathrm{APV}$ (Fig. 4A, APV) (DSI after sham-stimulation in APV, $18.2 \pm$ $2.5 \%, n=10$; after tetanization in APV, $32.0 \pm 2.7 \%, n=11$ ), indicating that NMDA receptors are not necessary for the induction of plasticity of endocannabinoid signaling (these results were confirmed with $50 \mu \mathrm{M}$ APV in a separate series of experiments; DSI after sham-stimulation in APV, $17.0 \pm 1.8 \%, n=6$; after tetanization in APV, $30.8 \pm 2.9 \%, n=6$ ). Interestingly, the broad-spectrum metabotropic glutamate receptor antagonist LY341495 $(200 \mu \mathrm{M})$ was also able to completely abolish the induction of DSI potentiation (Fig. 4A, LY341495) (DSI after sham-stimulation in LY341495, $20.5 \pm 2.7 \%, n=10$; after tetanization in LY341495, $18.5 \pm 1.9 \%, n=9$ ). Therefore, both non-NMDA ionotropic as well as metabotropic glutamate receptors are necessary for the afferent stimulation-induced potentiation of DSI. However, $\mathrm{GABA}_{\mathrm{A}}$ receptor activity is not required for this plasticity to occur, as the $\mathrm{GABA}_{\mathrm{A}}$ receptor blocker bicuculline $(10 \mu \mathrm{M})$ failed to inhibit the tetanus-induced potentiation of DSI (Fig. 4A, bicuculline) (DSI after sham-stimulation in bicuculline, $18.6 \pm 3.3 \%, n=9$; after tetanization in bicuculline, $31.7 \pm 2.6 \% ; n=10)$. Note also that the sensitivity of the tetanusinduced potentiation of DSI to AMPA/kainate receptor blockade further distinguished this form of plasticity of endocannabinoid signaling from iLTD, which could be induced both in the presence or absence of NBQX (Chevaleyre and Castillo, 2003).

\section{Requirement of CB1 receptors for induction of tetanus- induced DSI potentiation in vitro}

Because high-frequency stimulation of Schaffer collaterals in hippocampal slices is known to transiently increase endocannabinoid levels (Stella et al., 1997), we next tested whether CB1 receptor activation is involved in DSI potentiation (same experimental paradigm as in the experiments of Fig. $4 A$ ). Tetanic stimulation, or sham stimulation, was applied in the presence of the CB1 antagonist SR141716A (Fig. 4A, sham-tet/tetanus during SR) (3 min perfusion with SR141716A was followed by tetanic- or sham stimulation, during which SR141716A perfusion was continued; total SR141716A perfusion, $6 \mathrm{~min}$ ), which in turn was followed by $>60$ min wash in control ACSF and then DSI was assessed. Importantly, when tetanic stimulation was performed in the presence of SR141716A, DSI potentiation did not occur (Fig. $4 B$, left and middle bar graphs) (DSI in cells from sham-tetanized slices, $17.9 \pm 2.6 \%, n=10$; in cells from slices tetanized in SR141716A, $15.6 \pm 2.1 \%, n=10)$. Therefore, a major conclusion from these observations, with significant relevance for the design of new strategies to oppose the long-term consequences of febrile seizures (see below), is that CB1 receptor activation is an absolute

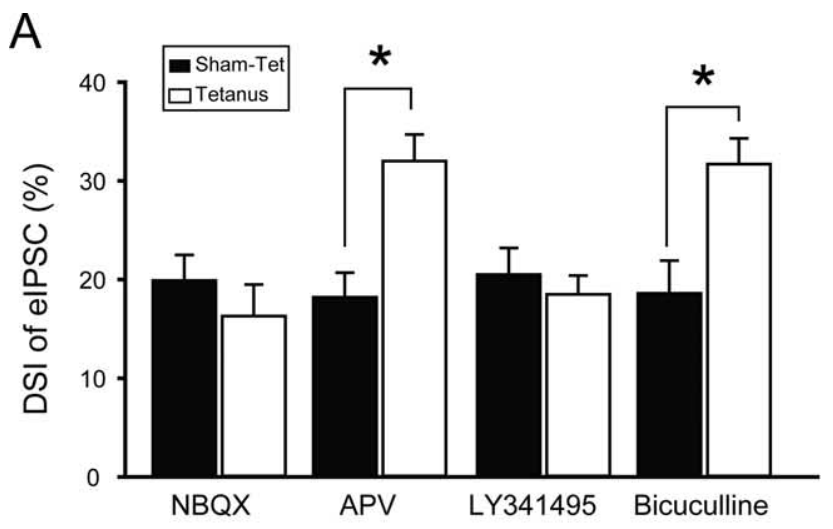

\section{B}
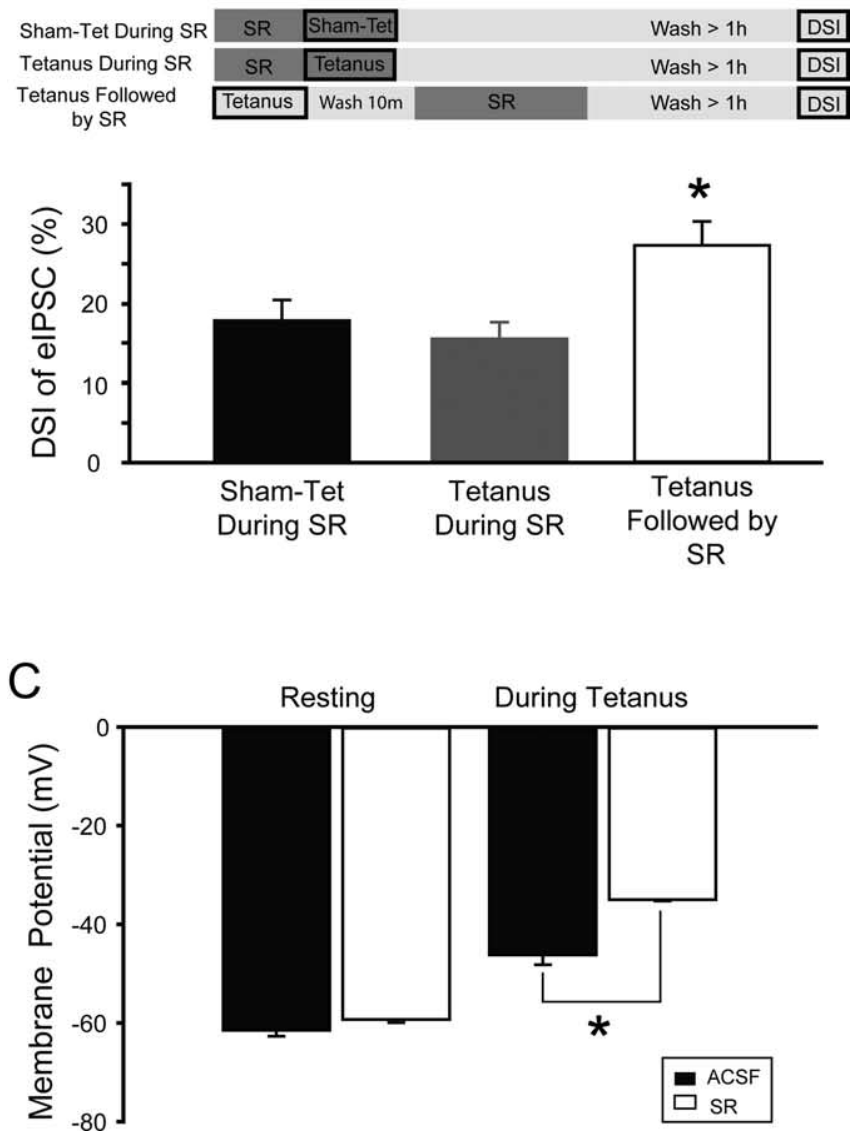

Figure 4. Activation of $A M P A / k a i n a t e, ~ m G l u R$, and $C B 1$ receptors is required during tetanus for potentiation of DSI. $A$, Tetanus-induced potentiation of DSI is blocked when NBQX (5 $\mu \mathrm{m})$, an AMPA/kainate receptor antagonist, or LY341495 (200 $\mu \mathrm{M})$, a broad spectrum mGluR antagonist, is present during tetanization. Blockade of NMDARs with APV $(10 \mu \mathrm{M})$, or blockade of $\mathrm{GABA}_{\mathrm{A}}$ receptors with bicuculline $(10 \mu \mathrm{m})$ during tetanization does not prevent potentiation of DSI. $\boldsymbol{B}$, Potentiation of DSI is prevented when SR141716, a CB1R antagonist, is present during tetanus (SR was applied for 6 min, which was followed by a $>60$ min wash in ACSF). To exclude the possibility that this effect was caused by an incomplete wash out of SR from the slice, a control experiment was performed in which tetanus was applied in the absence of $S R$, followed by a 6 min perfusion of the slice with SR, followed by a 60 min wash with ACSF (tetanus followed by SR). The presence of potentiated DSI in this experiment indicates that SR can be completely eliminated from the slice with a 60 min wash. The top panel demonstrates experimental protocol, where dark boxes indicate presence of SR in extracellular medium. $\boldsymbol{C}$, The presence of SR during tetanus does not decrease the effective activation of excitatory afferents. In fact, SR did not change the pretetanus resting membrane potential, but the average membrane potential during tetanic stimulation was depolarized in the presence of SR and, as detailed in the text, the number of action potentials elicited by each tetanic train was also increased in the presence of SR. 
requirement for the induction of this plasticity in endocannabinoid signaling.

A number of control experiments were performed to exclude alternative interpretations of the preceding tetanization experiments performed in the presence of SR141716A. First, the lack of DSI potentiation after tetanic stimulation in SR141716A was not attributable to incomplete wash-out of the drug (note that this is a potentially significant concern, because SR141716A blocks DSI), because DSI potentiation did take place when SR141716A was applied $10 \mathrm{~min}$ after the tetanus (Fig. $4 \mathrm{~B}$, tetanus followed by SR) (DSI in cells from slices that were tetanized in ACSF, then perfused with ACSF containing SR141716A for $6 \mathrm{~min}$, followed by $>60$ min wash in ACSF, $27.3 \pm 3.0 \%, n=10$ ).

Second, the blocking effect of SR141716A also could not be explained by a decreased amount of neuronal activity in SR141716A, because tetanic stimulation in the presence of SR141716A actually resulted in a larger average depolarization during tetanization, compared with tetanic stimulation in ACSF (Fig. 4C) (average membrane potential during the $100 \mathrm{~Hz}$ tetanus, calculated from 5-ms-long samples collected at $10 \mathrm{kHz}$, taken $2.5 \mathrm{~ms}$ after each stimulus during the tetanic train, when tetanization was performed in ACSF, $-46.2 \pm 2.0 \mathrm{mV}, n=4$; when tetanization was performed in SR141716A, $-35.0 \pm 0.3$ $\mathrm{mV}, n=5$; note that the resting membrane potential, measured before the tetanic stimulation was applied, was not altered by the presence of SR141716A, resting membrane potential in ACSF, $-61.5 \pm 1.2 \mathrm{mV}, n=4$; in SR141716A, $-59.3 \pm 0.6 \mathrm{mV}, n=5)$. Furthermore, tetanization in the presence of SR141716A also increased the number of action potentials that the CA1 pyramidal cells fired during the stimulation (number of action potentials per tetanic train in ACSF, $28.8 \pm 7.2, n=4$; in SR141716A, $50.0 \pm 7.4, n=5)$. Note that the higher number of action potentials in CA1 pyramidal cells during the tetanic stimulation in the presence of SR141716A compared with ACSF is in agreement with previous observations on the acute seizure-enhancing effects of SR141716A application in vivo (Wallace et al., 2002; Marsicano et al., 2003; Bernard et al., 2005).

Together, the results of these experiments demonstrated that both glutamate and $\mathrm{CB} 1$ receptors are involved in the mechanisms underlying DSI potentiation. Furthermore, these experiments also showed that application of the CB1 antagonist after the tetanus was not effective in preventing activity dependent DSI potentiation, indicating that activation of $\mathrm{CB} 1$ receptors is critical only during, but not after the induction period.

\section{CB1 receptor blockade during seizures inhibits seizure- induced DSI potentiation}

Can we use the previous insights into the in vitro induction mechanisms of activity-dependent DSI potentiation to prevent the DSI potentiation that takes place after HT in vivo? In agreement with previous reports (Chen et al., 2003), DSI was significantly increased in animals that were preinjected with vehicle (5\% alcohol, total injected volume, $70 \mu \mathrm{l}$ ) (see Materials and Methods) and subjected to HT 1 week before the recording session at age P10 (HT plus vehicle), compared with vehicle-injected, agematched littermate normothermic controls (Fig. 5A, vehicle, left pair of bar graphs) (DSI in cells from slices from control, vehicleinjected animals, $19.9 \pm 2.4 \%, n=9$; from HT vehicle-injected animals, $30.2 \pm 3.3 \%, n=10$ ), indicating that the vehicle used to dissolve SR141716A in the subsequent experiments did not interfere with DSI potentiation. However, when HT was induced in animals that were preinjected with SR141716A (in the same vehicle) at either high $(10 \mathrm{mg} / \mathrm{kg})$ or low $(1 \mathrm{mg} / \mathrm{kg})$ concentration
A

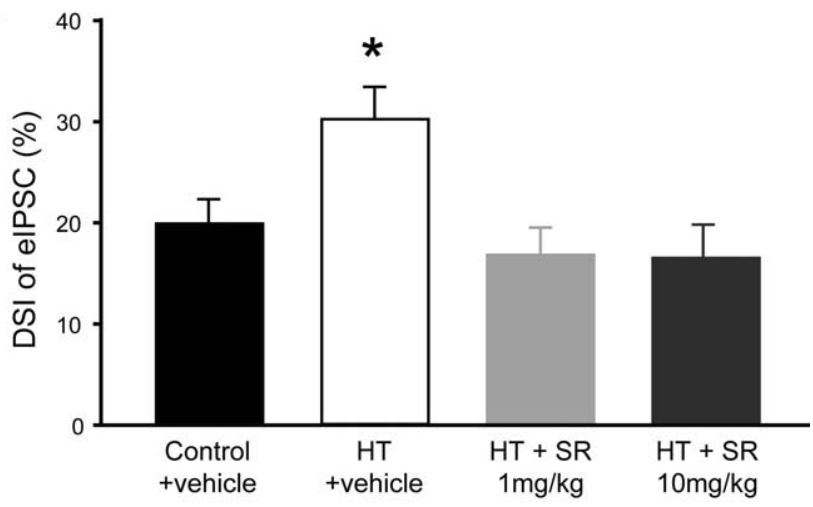

B
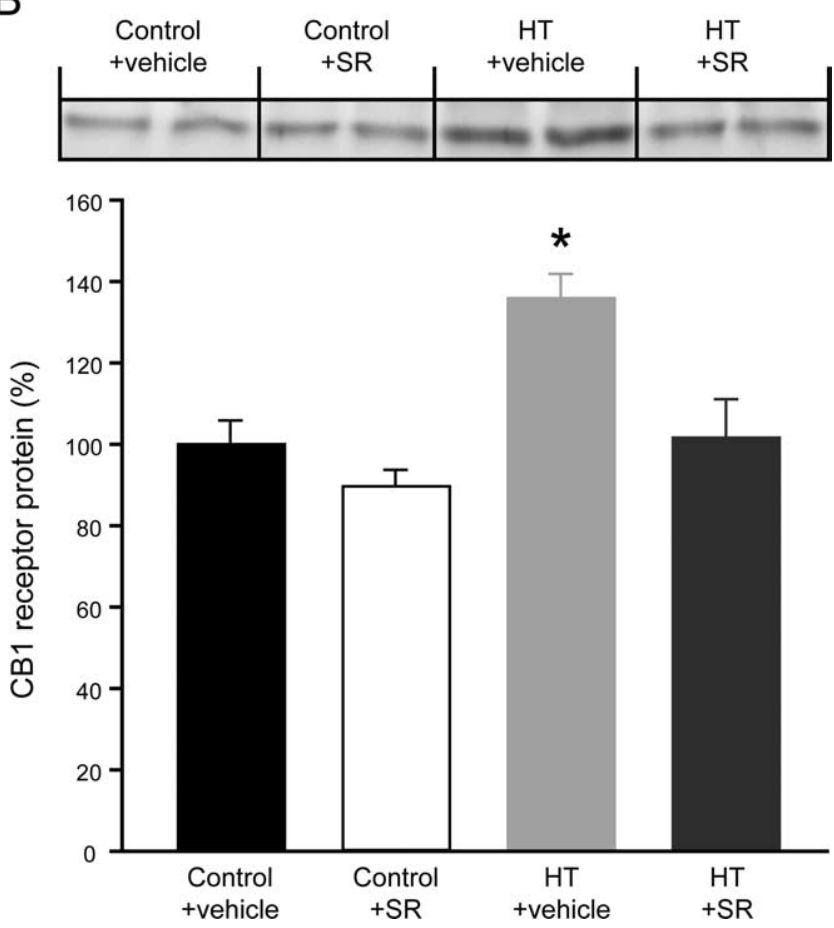

Figure 5. Blocking $C B 1$ receptors in vivo during experimental febrile seizures prevents both potentiation of DSI and increase in CB1 receptor number. $\boldsymbol{A}$, The potentiation of DSI observed after $\mathrm{HT}$ is prevented when SR is injected in vivo before $\mathrm{HT}$ induction at a dose of either 1 or 10 $\mathrm{mg} / \mathrm{kg}$. $\boldsymbol{B}$, Typical western blots of hippocampal tissue (top) and their quantitative analysis (bottom) demonstrate a significant (35.9\%) increase in the amount of $\mathrm{CB} 1$ receptor protein after HT (HT+ vehicle) as compared with littermate controls (either vehicle- or SR-injected controls). The injection of SR in vivo $(1 \mathrm{mg} / \mathrm{kg}$ ) before $\mathrm{HT}$ induction $(\mathrm{HT}+\mathrm{SR})$ prevents the increased expression of $\mathrm{CB} 1$ protein.

$1 \mathrm{~h}$ before the seizure induction, the potentiation of DSI did not take place (Fig. $5 A$, right pair of bar graphs, HT + SR) (DSI in cells from slices from HT animals preinjected with $1 \mathrm{mg} / \mathrm{kg}$ SR141716A before seizure induction, $16.8 \pm 2.7 \%, n=7$; from HT animals preinjected with $10 \mathrm{mg} / \mathrm{kg}$ SR141716A, $16.5 \pm 3.3 \%$, $n=8)$. Therefore, as predicted by the in vitro experiments, blockade of CB1 receptors prevents the upregulation of DSI by the experimental febrile seizures.

CB1 receptor blockade during febrile seizures abolishes the seizure-induced increase in CB1 receptor numbers

Previous results have shown that febrile seizures increase the number of CB1 receptors expressed in the hippocampus (as assessed with Western blotting) without altering the cell type- 
specificity of the $\mathrm{CB} 1$ receptor expression and without the sprouting of the perisomatic CB1-expressing axons in the CA1 layer (Chen et al., 2003). Interestingly, other forms of seizures (e.g., pilocaprineinduced seizures) have also been shown to result in a persistent increase in CB1 receptors (Wallace et al., 2003), indicating that upregulation of $\mathrm{CB} 1$ receptors may be a robust consequence of seizures. Because the increase in $\mathrm{CB} 1$ receptor numbers has been suggested to be a mechanism associated with the DSI potentiation resulting from febrile seizures (Chen et al., 2003), in the next series of experiments we determined whether the presence of CB1 antagonists during HT abolishes the long-term increase in $\mathrm{CB} 1$ receptors.

As illustrated in Figure 5B, CB1 receptor protein levels were significantly increased in Western blots in hippocampi from vehicle-injected animals that experienced febrile seizures (Fig. 5B, $\mathrm{HT}+$ vehicle) (percent CB1 levels in HT + vehicle animals, $135.9 \pm 6.0 \% ; n=4$ animals) compared with vehicle-injected, sham-treated littermate controls (Fig. $5 B$, control+vehicle) $(100.0 \pm 5.9 \% ; n=4$ animals) one week after the febrile seizures. Injection of SR141716A (1 mg/kg, i.p.) to control animals did not change the $\mathrm{CB} 1$ receptor expression levels (Fig. 5B, control+SR) (CB1 levels in control+SR animals, $89.7 \pm 4.1 \% ; n=4$ animals). In contrast to the HT+vehicle animals, however, CB1 levels were not persistently elevated after the febrile seizures in animals that were preinjected with SR141716A (1 $\mathrm{mg} / \mathrm{kg}$ ) (Fig. 5B, HT+SR) (CB1 levels in $\mathrm{HT}+\mathrm{SR}$ animals, $101.6 \pm 9.5 \% ; n=5$ animals). These data show that $\mathrm{CB} 1$ receptor blockade during seizure induction prevents the long-term elevation of CB1 receptor expression after febrile seizures.

CB1 receptor antagonism during seizure induction prevents the long-term increase in hippocampal network excitability after febrile seizures: in vitro and in vivo assessment

Febrile seizures are known to cause a long-lasting increase in hippocampal network excitability, as demonstrated by a decrease in threshold for self-sustaining, recurrent seizure-like electrical discharges after the application of brief high-frequency test stimuli in acute combined entorhino-hippocampal slices in vitro and by the decreased in vivo seizure threshold for the limbic convulsant kainate (Dube et al., 2000). Because CB1 receptor blockade prevented the in vivo HT-induced upregulation of DSI as well as the HT-induced increase in CB1 receptor numbers, in the next series of experiments we determined whether $\mathrm{CB} 1$ receptor blockade during seizure induction also prevents the development of long-term hyperexcitability induced by febrile seizures (Dube et al., 2000).
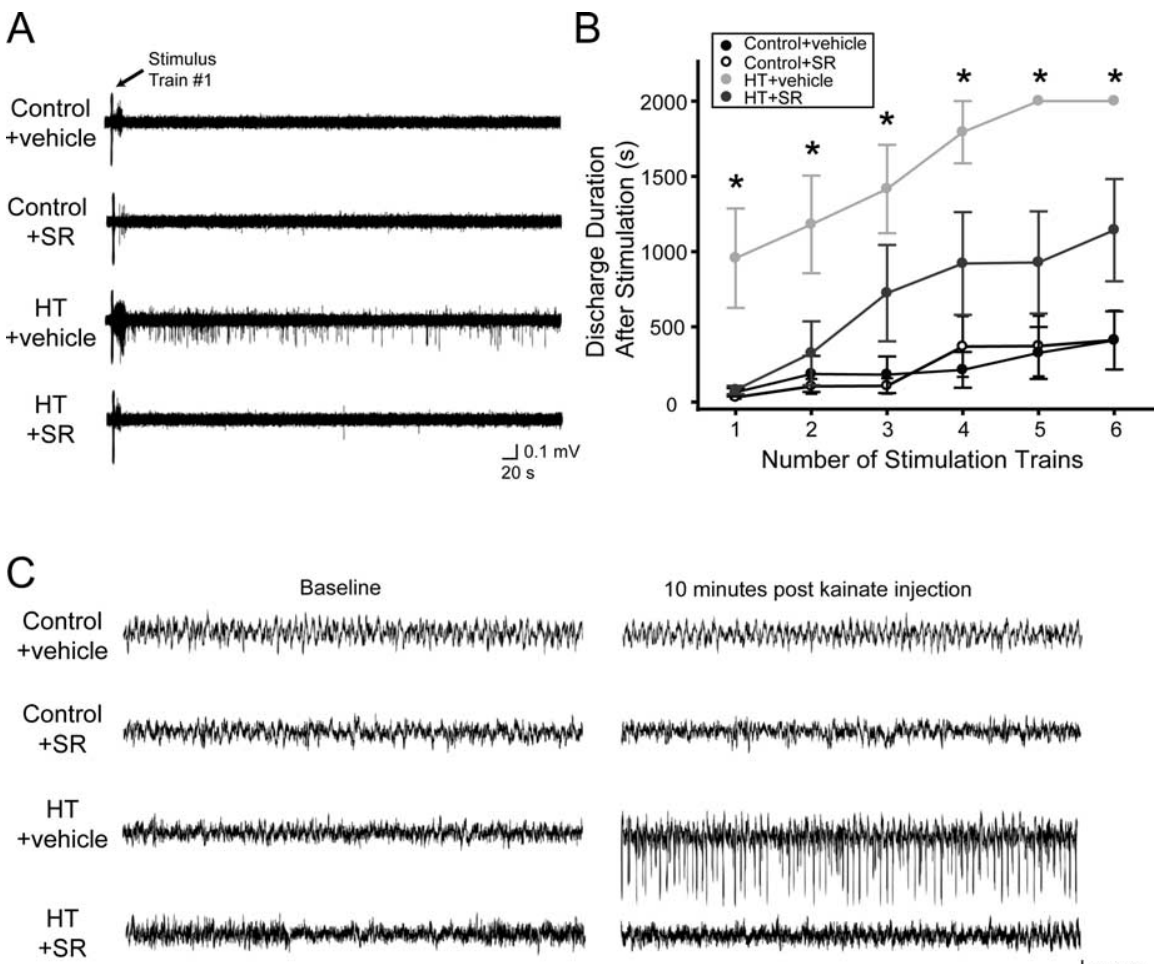

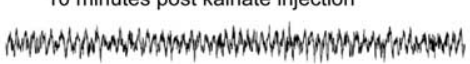
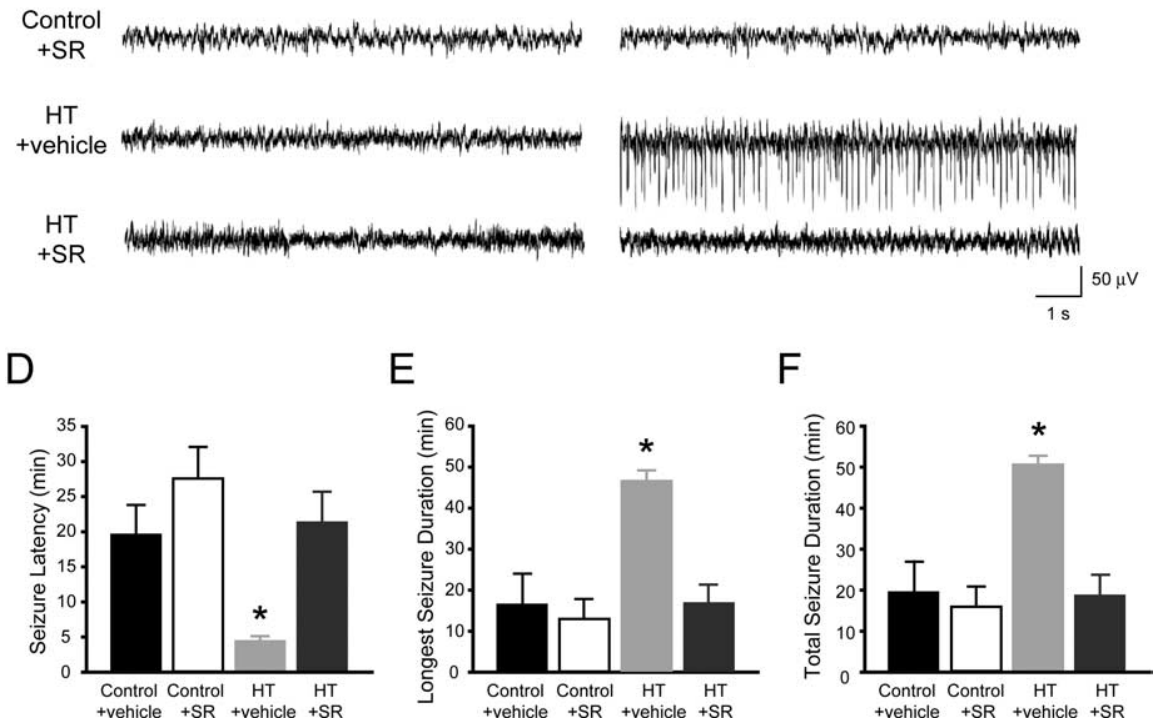

Figure 6. Blocking $C B 1$ receptors in vivo during febrile seizures prevents the long-lasting decrease in seizure threshold. $A-F$, Seizure thresholds were tested both with electrical stimulation in vitro at 1 week after febrile seizures $(\boldsymbol{A}, \boldsymbol{B})$ and with kainate in $\mathrm{Hz}$ ) in hippocampal-entorhinal slices leads to self-sustaining epileptiform discharges in vehicle-injected HT animals, but not in SR-injected HT animals or in controls. Recordings were performed 1 week after HT induction. Note that the high-frequency shorter than what is required for DSI potentiation). $\boldsymbol{B}$, Plot of stimulation train number versus the duration of spontaneous field discharges shows that the injection of SR, at $1 \mathrm{mg} / \mathrm{kg}$, prevents the increase in epileptiform activity seen after HT. C, Representainitiated in $\mathrm{HT}+$ vehicle animals but not in HT + SR (1 mg/kg) animals or control animals. $D$, The latency to seizure initiation is significantly decreased by HT (HT+ vehicle), but this decrease is prevented by injection of SR (HT+SR). $\boldsymbol{E}, \boldsymbol{F}$, SR injection prevents the increase seen after HT in both the duration of the longest single seizure and the cumulative duration of all seizures.

First, we measured the effect of CB1 receptor antagonism on limbic hyperexcitability using short trains of electrical stimuli to the Schaffer collaterals to measure seizure threshold, in combined hippocampal-entorhinal slices prepared 1 week after the experimental febrile seizure induction (note that the stimulus trains were used to probe the excitability of the network, not to induce changes in DSI; accordingly, these test stimuli were considerably shorter than what is required for DSI potentiation). As shown in Figure 6A, the first stimulus train caused only a few, short after-discharges without sustained field activity in combined hippocampal-entorhinal slices from control animals, or from control animals injected with SR141716A (1 mg/kg, i.p.) (Fig. 6A, control+vehicle, control+SR). In contrast, even the 
first stimulus train evoked the characteristic, previously described (Dube et al., 2000), self-sustaining population activity in slices from animals that experienced experimental febrile seizures 1 week before the recording and were injected with vehicle before the febrile seizures (Fig. 6A, HT+vehicle), demonstrating that febrile seizures prominently increased hippocampal network excitability in a long-term manner.

However, when the animals were preinjected with SR141716A and then subjected to experimental febrile seizures, the network hyperexcitability was decreased compared with the HT plus vehicle animals (Fig. 6A, HT+SR). Population data for these experiments, for consecutive test stimuli (delivered every $10 \mathrm{~min}$ ) is shown in Figure $6 B$ (number of slices: control+vehicle, $n=8$, from $n=4$ animals; control $+\mathrm{SR}, n=8$, from $n=4$ animals; HT + vehicle, $n=9$, from $n=4$ animals; HT + SR, $n=9$, from $n=4$ animals; note that, because the clinical definition of status epilepticus is $30 \mathrm{~min}$ of seizures, the recordings were terminated if the self-sustaining activity lasted longer than $35 \mathrm{~min}$, resulting in the apparent plateau observable after five stimulation trains for the activity from HT+vehicle slices in Fig. $6 \mathrm{~B}$ ). Therefore, these data demonstrate that the presence of SR141716A during HT induction significantly limited the development of network hyperexcitability resulting from the febrile seizures.

Second, we performed experiments to measure the effect of CB1 antagonism on seizure-induced long-term changes in seizure thresholds, by assessing seizure threshold from in vivo hippocampal EEG recordings after the application of the prototypic limbic convulsant kainate $(5 \mathrm{mg} / \mathrm{kg}$, i.p.), 6 weeks after the experimental febrile seizures. In agreement with previous reports (Dube et al., 2000), animals that experienced HT exhibited a significant decrease in threshold for kainate-induced seizures (Fig. 6C) compared with controls. Specifically, in animals that experienced HT after vehicle injection, application of kainate resulted in seizures that appeared significantly faster and lasted significantly longer (Fig. 6D-F) (seizure latency: control+vehicle, $19.6 \pm 4.2 \mathrm{~min}, n=7$; HT + vehicle, $4.5 \pm 0.7 \mathrm{~min}$, $n=8$; duration of longest seizure episode: control+vehicle, $16.0 \pm 7.7 \mathrm{~min}$; HT + vehicle, $46.1 \pm 3.0 \mathrm{~min}$; total seizure duration: control+vehicle, $19.5 \pm 7.5 \mathrm{~min}$; HT+vehicle, $50.5 \pm 2.3$ $\mathrm{min})$. In contrast, animals that experienced febrile seizures in the presence of SR141716A showed no evidence of significantly decreased seizure thresholds after the kainate challenge (Fig. $6 C-F$ ) (seizure latency: control+SR, $27.6 \pm 4.5 \mathrm{~min}, n=6$; $\mathrm{HT}+\mathrm{SR}$, $21.4 \pm 4.3 \mathrm{~min}, n=8$; duration of longest seizure episode: control+SR, $12.9 \pm 4.6 \mathrm{~min} ; \mathrm{HT}+\mathrm{SR}, 16.7 \pm 4.8 \mathrm{~min}$; total seizure duration: control $+\mathrm{SR}, 15.9 \pm 5.0 \mathrm{~min} ; \mathrm{HT}+\mathrm{SR}, 18.7 \pm$ $4.9 \mathrm{~min}$ ). These data demonstrate that $\mathrm{CB} 1$ antagonism during febrile seizures can significantly counteract and even prevent the long-term, seizure-induced decrease in seizure threshold in the hippocampus.

In principle, SR141716A may have decreased long-term hyperexcitability by decreasing febrile seizures. However, this was highly unlikely, because SR141716A actually enhanced neuronal depolarization and firing during tetanization (Fig. 4C), and SR141716A has been shown to act as a proconvulsant in vivo (Wallace et al., 2002; Marsicano et al., 2003; Bernard et al., 2005). Indeed, we found no alterations in parameters of HT induction in the animals involved in the in vitro and in vivo assessment experiments. First, application of SR141716A did not affect the baseline body temperature (HT+vehicle, $32.9 \pm 0.4^{\circ} \mathrm{C}, n=21$; $\left.\mathrm{HT}+\mathrm{SR}, 33.0 \pm 0.3^{\circ} \mathrm{C}, n=22\right)$. Second, the number of seizure sessions during the $\sim 30$-min-long experimental febrile seizure-induction procedure (see Materials and Methods) was also unchanged (HT+vehicle, $5.8 \pm 0.3$; $\mathrm{HT}+\mathrm{SR}, 6.5 \pm 0.3$; note that, if anything, there was a nonsignificant trend toward more seizure sessions in SR141716A, which obviously could not explain the protection against long-term hyperexcitability provided by SR141716A). Third, the threshold temperature for febrile seizures was also unaltered by SR141716A (HT+vehicle, $40.5 \pm$ $\left.0.3^{\circ} \mathrm{C} ; \mathrm{HT}+\mathrm{SR}, 39.8 \pm 0.2^{\circ} \mathrm{C}\right)$.

We also performed experiments to determine whether SR141716A was also effective in blocking the long-term effects of febrile seizures on seizure thresholds if applied after the start of the febrile seizure induction period. Therefore, the experiments described above in connection with Figure $6 C-F$ were repeated with SR141716A injected ( $1 \mathrm{mg} / \mathrm{kg}$, i.p.) 2 min after the start of the febrile seizures (as above, the assessment of seizure thresholds with kainate was performed 6 weeks after the febrile seizures). The data showed that the animals that experienced febrile seizures with SR141716A injected 2 min after the start of the seizure induction period showed no evidence of decreased seizure thresholds after the kainate challenge (seizure latency: control+vehicle, $20.1 \pm 4.6 \mathrm{~min}, n=9$; $\mathrm{HT}+$ vehicle, $4.8 \pm 0.6$ min, $n=8$; HT $+\mathrm{SR}, 16.0 \pm 3.0 \mathrm{~min} ; n=8$; duration of longest seizure episode: control+vehicle, $18.0 \pm 4.3 \mathrm{~min}$; HT + vehicle, $48.6 \pm 1.7 \mathrm{~min}$; HT $+\mathrm{SR}, 9.9 \pm 2.9 \mathrm{~min}$; total seizure duration: control+vehicle, $25.4 \pm 3.8 \mathrm{~min}$; $\mathrm{HT}+$ vehicle, $51.7 \pm 1.4 \mathrm{~min}$; $\mathrm{HT}+\mathrm{SR}, 18.9 \pm 2.2 \mathrm{~min})$. Thus, CB1 antagonism can significantly counteract and prevent the long-term, seizure-induced decrease in seizure threshold in the hippocampus not only when SR141716A is preinjected before the onset of the seizures, but also when it is injected $2 \mathrm{~min}$ after the start of febrile seizure induction.

Finally, we sought to provide additional evidence for the acute proconvulsant action of SR141716A. For technical reasons, we could not reliably record EEG seizures during febrile seizure induction, therefore, we measured the effect of SR141716A (1 mg/ $\mathrm{kg}$ ) on acute in vivo kainate-induced seizures in P10 animals. As expected, the data showed that SR141716A had a significant proconvulsant effect (seizure latency after kainate injection in vehicle injected controls, $17.3 \pm 6.6 \mathrm{~min}, n=5$; in SR141716A injected animals, $6.5 \pm 1.8 \mathrm{~min}, n=5$ ). The acute proconvulsant action of $\mathrm{CB} 1$ receptor blockade is in full agreement with our in vitro data described above indicating more depolarized membrane potentials and more action potential discharges in response to tetanic stimulation of afferents in the presence of SR141716A (Fig. 4C and related data), and it also agrees with previous reports from different epilepsy models on the acute seizure enhancing effects of SR141716A (Wallace et al., 2002; Marsicano et al., 2003; Bernard et al., 2005). Therefore, CB1 receptor blockade during experimental febrile seizures has a significant inhibitory effect on the long-term reduction in seizure threshold despite its acute proconvulsant actions.

\section{Discussion}

\section{Role for CB1 receptors in inducing plasticity of} endocannabinoid signaling and limbic hyperexcitability

CB1 receptors are the most numerous G-protein-coupled receptors in the brain (Herkenham et al., 1990; Matsuda et al., 1990), strategically positioned at both GABAergic and glutamatergic synapses to regulate neurotransmitter release (Katona et al., 1999, 2006; Kawamura et al., 2006; Monory et al., 2006). As indicated by their numerical abundance and specific expression patterns, CB1 receptors modulate hippocampal excitability in both healthy and pathological states (Hajos et al., 2000; Wilson et al., 2001; Carlson et al., 2002; Chen et al., 2003; Wallace et al., 2003; 
Monory et al., 2006). Here, we showed that prevention of endocannabinoid signaling plasticity decreases the persistent effects of prolonged febrile seizures on limbic excitability.

To determine key steps in the induction pathway for DSI plasticity, we first developed an in vitro model of DSI potentiation allowing rapid testing of pharmacological agents. Strong tetanic stimulation of excitatory afferents in slices replicated a number of effects of in vivo febrile seizures. Namely, tetanic stimulation enhanced DSI amplitude and duration, increased CB1-mediated tonic inhibition of GABA release, and did not significantly modify DSE. Activity-dependent DSI potentiation in slices was rapid and occluded by previous febrile seizures, and the induction mechanism required non-NMDA ionotropic and metabotropic glutamate receptors, and $\mathrm{CB} 1$ receptors.

Taking advantage of these mechanistic insights, we returned to the in vivo febrile seizure paradigm to demonstrate that CB1 receptor antagonism during HT induction prevents three major consequences of febrile seizures, namely, the persistent DSI potentiation and increase in CB1 receptors, and the development of long-lasting limbic hyperexcitability. It is interesting to note that the key finding of the present paper (i.e., that $\mathrm{CB} 1$ receptors are required for the induction of both seizure-induced endocannabinoid plasticity and long-term changes in seizure thresholds), could not have been predicted from our previous observation that febrile seizures persistently modify endocannabinoid signaling pathways (Chen et al., 2003). The present results may provide novel therapeutic avenues for infants who are most at risk of developing long-term limbic hyperexcitability from prolonged febrile seizures (Annegers et al., 1987; Cendes et al., 1993; French et al., 1993; Hesdorffer and Hauser, 2002).

\section{DSI potentiation and iLTD: two distinct forms of endocannabinoid plasticity modulating GABAergic synaptic transmission}

Persistent DSI potentiation indicates that neuronal activity can modify CB1 receptor-dependent short-term plasticity of GABAergic transmission in a long-term manner. Therefore, activity-dependent DSI potentiation first described in this paper joins the recently discovered iLTD (Chevaleyre and Castillo, 2003,2004 ) as two mechanisms by which glutamatergic afferent activity can result in long-term depression of GABA-release from $\mathrm{CB} 1$ receptor expressing GABAergic axons. DSI potentiation is clearly distinct from iLTD, because tetanic stimulation that resulted in DSI potentiation did not depress sIPSCs, eIPSCs, or uIPSCs. A major reason why tetanic stimulation of Schaffer collaterals did not result in iLTD is likely to be that iLTD is a property of $\mathrm{CB} 1$ expressing interneuronal inputs to pyramidal cell dendrites (Chevaleyre and Castillo, 2003, 2004), but not of perisomatic inputs studied in this paper. Furthermore, in contrast to iLTD induction, DSI potentiation requires AMPA/kainate receptors. In contrast, metabotropic glutamate receptor antagonists block the induction of both DSI potentiation (present study) and iLTD (Chevaleyre and Castillo, 2003, 2004), indicating shared molecular steps, likely related to the production of endocannabinoids (Maejima et al., 2005).

\section{Mechanisms of activity-dependent plasticity of DSI}

The key events resulting in DSI potentiation can be delineated as follows. The initial steps involve glutamate release and the activation of both AMPA/kainate ionotropic and metabotropic glutamate receptors, which would be expected to result in the postsynaptic synthesis and release of endocannabinoids. The endocannabinoid is likely to be 2-AG, because Schaffer collateral stimulation has been shown to transiently increase 2-AG but not anandamide levels (Stella et al., 1997), although kainate-induced seizures are accompanied by rapid increases in both $2-\mathrm{AG}$ and anandamide (Wettschureck et al., 2006) or anandamide alone (Marsicano et al., 2003). Exactly how tetanus-induced spike in endocannabinoid levels leads to DSI potentiation is not fully understood. On the presynaptic side, elevation of CB1 receptor levels after febrile seizures has been suggested to be a mechanism contributing to enhanced DSI amplitude (Chen et al., 2003). Increased $\mathrm{CB} 1$ receptor levels are expected to also prolong DSI and enhance tonic inhibition of GABA release (for detailed discussion, see Chen et al., 2003), which are two additional consequences of both tetanic stimulation and febrile seizures. Whether upregulation of CB1 receptors occurs after tetanic stimulation in slices is unclear, but it could take place through several potential mechanisms, including the rapid movement of $\mathrm{CB} 1$ receptors closer to the release sites from large receptor pools (Nyiri et al., 2005). On the postsynaptic side, one possibility is that episodes of strong glutamate receptor activation result in long-lasting priming of the activity of certain $\mathrm{Ca}^{2+}$-sensitive endocannabinoid synthetic enzymes (Bisogno et al., 2003; Hashimotodani et al., 2005; Katona et al., 2006).

Although details will need to be investigated further, a critical insight provided by the present study is that $\mathrm{CB} 1$ receptor activation is a key step in DSI potentiation, both after tetanic stimulation in vitro and after febrile seizures in vivo. Application of SR141716A prevents CB1 receptor activation at the terminals of $\mathrm{CCK}^{+}$basket cells, which may be necessary for the downstream molecular steps leading to long-term presynaptic alterations in the endocannabinoid sensitivity of GABA release. Alternatively, it is possible that $\mathrm{CB} 1$ receptor blockade acted through the prevention of CB1 receptor activation on glutamatergic terminals, although it is difficult to see how that would interfere with DSI potentiation, especially because blockade of CB1 receptors on glutamatergic terminals would be expected to abolish DSE during tetanus and febrile seizures, resulting in even larger increases in glutamate release. It is interesting to note also that neuronal activity potentiated both the CB1-dependent phasic (DSI) and tonic inhibition of GABA release, without altering DSE in a longterm manner. As with the potentiation of DSI, the enhancement in the tonic inhibition of GABA release by $\mathrm{CB} 1$ receptors may have resulted from a variety of presynaptic and/or postsynaptic processes, including increases in the number or constitutive activity of presynaptic $\mathrm{CB} 1$ receptors, or through augmentation of the tonic synthesis and release of endocannabinoid ligands from postsynaptic cells. It will also be interesting to establish in future studies whether $\mathrm{CB} 1$ receptor blockade during febrile seizures also prevents other known consequences of these seizures, including potentiation of GABA release and enhancement of $I_{\mathrm{h}}$ (Chen et al., 1999, 2001).

\section{$\mathrm{CB} 1$ receptor blockade is acutely proconvulsant but prevents chronic increases in limbic hyperexcitability caused by seizures}

Paradoxically, CB1 receptor blockade inhibited development of long-term decreases in seizure thresholds despite acute proconvulsant actions of SR141716A. That a proconvulsant drug can exert beneficial chronic effects on seizure thresholds is a novel finding with major potential implications for the ongoing search for new antiepileptic compounds. The proconvulsant nature of SR141716A is well established, because it can promote seizurelike discharges both in vitro and in vivo in different seizure paradigms and in different age groups (Wallace et al., 2002; Marsi- 
cano et al., 2003; Bernard et al., 2005; present study). Although the exact reason for the excitability-promoting actions of acute $\mathrm{CB} 1$ receptor blockade is not fully established, the most likely mechanism is blockade of activity-dependent depression of glutamate release (Marsicano et al., 2003; Monory et al., 2006) (i.e., antagonism of DSE). That SR141716A significantly decreased the long-term effects of febrile seizures on seizure thresholds despite its acute proconvulsant actions indicates that $\mathrm{CB} 1$ receptors play a critical role in inducing persistent changes in limbic networks during seizures, which should inspire future research for therapeutic applications. Some caveats will need to be carefully considered in this regard, including the acute proconvulsant actions of SR141716A that would have to be counteracted with anticonvulsant medications. In contrast, SR141716A shows a promising safety record in clinical trials as a potent antiobesity (and antismoking) agent (Despres et al., 2005; Pi-Sunyer et al., 2006), indicating that its long-term administration may be a possible method to prevent the plasticity of endocannabinoid signaling and long-term limbic network hyperexcitability after prolonged childhood seizures.

Future projects will need to establish exactly what kinds of manipulations of CB1 receptor-dependent signaling systems are the most beneficial under different conditions. A recent study showed that CB1 receptors on glutamate terminals are particularly important in regulating kainate-induced seizures, suggesting that boosting $\mathrm{CB} 1$ receptor-mediated control of glutamate release is the logical strategy for acute seizure control (Monory et al., 2006). In contrast, our results indicate that the opposite strategy (i.e., the blockade of $\mathrm{CB} 1$ receptors during seizures) may be the most beneficial intervention to counteract the long-term effects of childhood seizures, even if the blockade of CB1 receptors worsens the seizures acutely. These results indicate that the endocannabinoid system is likely to provide exciting new opportunities to develop fundamentally novel therapeutical strategies to prevent the long-term effects of prolonged seizures in infancy.

\section{References}

Annegers JF, Hauser WA, Shirts SB, Kurland LT (1987) Factors prognostic of unprovoked seizures after febrile convulsions. N Engl J Med 316:493-498.

Baram TZ, Gerth A, Schultz L (1997) Febrile seizures: an appropriate-aged model suitable for long-term studies. Brain Res Dev Brain Res 98:265-270

Beau FE, Alger BE (1998) Transient suppression of GABAA-receptormediated IPSPs after epileptiform burst discharges in CA1 pyramidal cells. J Neurophysiol 79:659-669.

Bender RA, Dube C, Gonzalez-Vega R, Mina EW, Baram TZ (2003) Mossy fiber plasticity and enhanced hippocampal excitability, without hippocampal cell loss or altered neurogenesis, in an animal model of prolonged febrile seizures. Hippocampus 13:399-412.

Bernard C, Milh M, Morozov YM, Ben-Ari Y, Freund TF, Gozlan H (2005) Altering cannabinoid signaling during development disrupts neuronal activity. Proc Natl Acad Sci USA 102:9388-9393.

Bisogno T, Howell F, Williams G, Minassi A, Cascio MG, Ligresti A, Matias I, Schiano-Moriello A, Paul P, Williams EJ, Gangadharan U, Hobbs C, Di Marzo V, Doherty P (2003) Cloning of the first sn1-DAG lipases points to the spatial and temporal regulation of endocannabinoid signaling in the brain. J Cell Biol 163:463-468.

Blair RE, Deshpande LS, Sombati S, Falenski KW, Martin BR, DeLorenzo RJ (2006) Activation of the cannabinoid type-1 receptor mediates the anticonvulsant properties of cannabinoids in the hippocampal neuronal culture models of acquired epilepsy and status epilepticus. J Pharmacol Exp Ther 317:1072-1078.

Bodor AL, Katona I, Nyiri G, Mackie K, Ledent C, Hajos N, Freund TF (2005) Endocannabinoid signaling in rat somatosensory cortex: laminar differences and involvement of specific interneuron types. J Neurosci 25:6845-6856.
Bouaboula M, Perrachon S, Milligan L, Canat X, Rinaldi-Carmona M, Portier M, Barth F, Calandra B, Pecceu F, Lupker J, Maffrand JP, Le Fur G, Casellas P (1997) A selective inverse agonist for central cannabinoid receptor inhibits mitogen-activated protein kinase activation stimulated by insulin or insulin-like growth factor 1. Evidence for a new model of receptor/ligand interactions. J Biol Chem 272:22330-22339.

Carlson G, Wang Y, Alger BE (2002) Endocannabinoids facilitate the induction of LTP in the hippocampus. Nat Neurosci 5:723-724.

Cendes F, Andermann F, Dubeau F, Gloor P, Evans A, Jones-Gotman M, Olivier A, Andermann E, Robitaille Y, Lopes-Cendes I, Peters T, Melanson D (1993) Early childhood prolonged febrile convulsions, atrophy and sclerosis of mesial structures, and temporal lobe epilepsy: an MRI volumetric study. Neurology 43:1083-1087.

Chen K, Baram TZ, Soltesz I (1999) Febrile seizures in the developing brain result in persistent modification of neuronal excitability in limbic circuits. Nat Med 5:888-894.

Chen K, Aradi I, Thon N, Eghbal-Ahmadi M, Baram TZ, Soltesz I (2001) Persistently modified h-channels after complex febrile seizures convert the seizure-induced enhancement of inhibition to hyperexcitability. Nat Med 7:331-337.

Chen K, Ratzliff A, Hilgenberg L, Gulyas A, Freund TF, Smith M, Dinh TP, Piomelli D, Mackie K, Soltesz I (2003) Long-term plasticity of endocannabinoid signaling induced by developmental febrile seizures. Neuron 39:599-611.

Chesher GB, Jackson DM (1974) Anticonvulsant effects of cannabinoids in mice: drug interactions within cannabinoids and cannabinoid interactions with phenytoin. Psychopharmacologia 37:255-264.

Chevaleyre V, Castillo PE (2003) Heterosynaptic LTD of hippocampal GABAergic synapses: a novel role of endocannabinoids in regulating excitability. Neuron 38:461-472.

Chevaleyre V, Castillo PE (2004) Endocannabinoid-mediated metaplasticity in the hippocampus. Neuron 43:871-881.

Chiu P, Olsen DM, Borys HK, Karler R, Turkanis SA (1979) The influence of cannabidiol and delta 9-tetrahydrocannabinol on cobalt epilepsy in rats. Epilepsia 20:365-375.

Consroe P, Wolkin A (1977) Cannabidiol-antiepileptic drug comparisons and interactions in experimentally induced seizures in rats. J Pharmacol Exp Ther 201:26-32.

Corcoran ME, McCaughran Jr JA, Wada JA (1973) Acute antiepileptic effects of 9-tetrahydrocannabinol in rats with kindled seizures. Exp Neurol 40:471-483.

Despres JP, Golay A, Sjostrom L (2005) Effects of rimonabant on metabolic risk factors in overweight patients with dyslipidemia. N Engl J Med 353:2121-2134.

Dube C, Chen K, Eghbal-Ahmadi M, Brunson K, Soltesz I, Baram TZ (2000) Prolonged febrile seizures in the immature rat model enhance hippocampal excitability long term. Ann Neurol 47:336-344.

Dube C, Richichi C, Bender RA, Chung G, Litt B, Baram TZ (2006) Temporal lobe epilepsy after experimental prolonged febrile seizures: prospective analysis. Brain 129:911-922.

Foldy C, Neu A, Jones MV, Soltesz I (2006) Presynaptic, activity-dependent modulation of cannabinoid type 1 receptor-mediated inhibition of GABA release. J Neurosci 26:1465-1469.

French JA, Williamson PD, Thadani VM, Darcey TM, Mattson RH, Spencer SS, Spencer DD (1993) Characteristics of medial temporal lobe epilepsy: I. Results of history and physical examination. Ann Neurol 34:774-780.

Glickfeld LL, Scanziani M (2006) Distinct timing in the activity of cannabinoid-sensitive and cannabinoid-insensitive basket cells. Nat Neurosci 9:807-815.

Hajos N, Katona I, Naiem SS, MacKie K, Ledent C, Mody I, Freund TF (2000) Cannabinoids inhibit hippocampal GABAergic transmission and network oscillations. Eur J Neurosci 12:3239-3249.

Hashimotodani Y, Ohno-Shosaku T, Tsubokawa H, Ogata H, Emoto K, Maejima T, Araishi K, Shin HS, Kano M (2005) Phospholipase C $\beta$ serves as a coincidence detector through its $\mathrm{Ca}^{2+}$ dependency for triggering retrograde endocannabinoid signal. Neuron 45:257-268.

Herkenham M, Lynn AB, Little MD, Johnson MR, Melvin LS, de Costa BR, Rice KC (1990) Cannabinoid receptor localization in brain. Proc Natl Acad Sci USA 87:1932-1936.

Hesdorffer DC, Hauser WA (2002) Febrile seizures and the risk of epilepsy. In: Febrile seizures (Baram TZ, Shinnar S, eds), pp 63-76. San Diego: Academic. 
Hoffman AF, Lupica CR (2000) Mechanisms of cannabinoid inhibition of $\mathrm{GABA}_{\mathrm{A}}$ synaptic transmission in the hippocampus. J Neurosci 20:2470-2479.

Hurst DP, Lynch DL, Barnett-Norris J, Hyatt SM, Seltzman HH, Zhong M, Song $\mathrm{ZH}, \mathrm{Nie}$ J, Lewis D, Reggio PH (2002) N-(piperidin-1-yl)-5-(4-chlorophenyl)-1-(2,4-dichlorophenyl)-4-methyl-1H-pyrazole-3-carboxamide (SR141716A) interaction with LYS 3.28(192) is crucial for its inverse agonism at the cannabinoid CB1 receptor. Mol Pharmacol 62:1274-1287.

Karler R, Cely W, Turkanis SA (1974) Anticonvulsant properties of delta 9-tetrahydrocannabinol and other cannabinoids. Life Sci 15:931-947.

Katona I, Sperlagh B, Sik A, Kafalvi A, Vizi ES, Mackie K, Freund TF (1999) Presynaptically located CB1 cannabinoid receptors regulate GABA release from axon terminals of specific hippocampal interneurons. J Neurosci 19:4544-4558.

Katona I, Urban GM, Wallace M, Ledent C, Jung KM, Piomelli D, Mackie K, Freund TF (2006) Molecular composition of the endocannabinoid system at glutamatergic synapses. J Neurosci 26:5628-5637.

Kawamura Y, Fukaya M, Maejima T, Yoshida T, Miura E, Watanabe M, Ohno-Shosaku T, Kano M (2006) The CB1 cannabinoid receptor is the major cannabinoid receptor at excitatory presynaptic sites in the hippocampus and cerebellum. J Neurosci 26:2991-3001.

Kim J, Isokawa M, Ledent C, Alger BE (2002) Activation of muscarinic acetylcholine receptors enhances the release of endogenous cannabinoids in the hippocampus. J Neurosci 22:10182-10191.

Kreitzer AC, Regehr WG (2001) Cerebellar depolarization-induced suppression of inhibition is mediated by endogenous cannabinoids. J Neurosci 21:RC174.

Landsman RS, Burkey TH, Consroe P, Roeske WR, Yamamura HI (1997) SR141716A is an inverse agonist at the human cannabinoid CB1 receptor. Eur J Pharmacol 334:R1-2.

Llano I, Leresche N, Marty A (1991) Calcium entry increases the sensitivity of cerebellar Purkinje cells to applied GABA and decreases inhibitory synaptic currents. Neuron 6:565-574.

Maejima T, Oka S, Hashimotodani Y, Ohno-Shosaku T, Aiba A, Wu D, Waku K, Sugiura T, Kano M (2005) Synaptically driven endocannabinoid release requires $\mathrm{Ca}^{2+}$-assisted metabotropic glutamate receptor subtype 1 to phospholipase $\mathrm{C} \beta 4$ signaling cascade in the cerebellum. J Neurosci 25:6826-6835.

Marsicano G, Goodenough S, Monory K, Hermann H, Eder M, Cannich A, Azad SC, Cascio MG, Gutierrez SO, van der Stelt M, Lopez-Rodriguez ML, Casanova E, Schutz G, Zieglgansberger W, Di Marzo V, Behl C, Lutz B (2003) CB1 cannabinoid receptors and on-demand defense against excitotoxicity. Science 302:84-88.

Martin LA, Wei DS, Alger BE (2001) Heterogeneous susceptibility of GABA(A) receptor-mediated IPSCs to depolarization-induced suppression of inhibition in rat hippocampus. J Physiol (Lond) 532:685-700.

Matsuda LA, Lolait SJ, Brownstein MJ, Young AC, Bonner TI (1990) Structure of a cannabinoid receptor and functional expression of the cloned cDNA. Nature 346:561-564.

Monory K, Massa F, Egertova M, Eder M, Blaudzun H, Westenbroek R, Kelsch W, Jacob W, Marsch R, Ekker M, Long J, Rubenstein JL, Goebbels S, Nave KA, During M, Klugmann M, Wolfel B, Dodt HU, Zieglgansberger W, Wotjak CT, et al. (2006) The endocannabinoid system controls key epileptogenic circuits in the hippocampus. Neuron 51:455-466.

Nyiri G, Cserep C, Szabadits E, Mackie K, Freund TF (2005) CB1 cannabinoid receptors are enriched in the perisynaptic annulus and on preterminal segments of hippocampal GABAergic axons. Neuroscience 136:811-822.

Ohno-Shosaku T, Maejima T, Kano M (2001) Endogenous cannabinoids mediate retrograde signals from depolarized postsynaptic neurons to presynaptic terminals. Neuron 29:729-738.

Ohno-Shosaku T, Tsubokawa H, Mizushima I, Yoneda N, Zimmer A, Kano M (2002) Presynaptic cannabinoid sensitivity is a major determinant of depolarization-induced retrograde suppression at hippocampal synapses. J Neurosci 22:3864-3872.

Pan X, Ikeda SR, Lewis DL (1998) SR 141716A acts as an inverse agonist to increase neuronal voltage-dependent $\mathrm{Ca}^{2+}$ currents by reversal of tonic CB1 cannabinoid receptor activity. Mol Pharmacol 54:1064-1072.

Pi-Sunyer FX, Aronne LJ, Heshmati HM, Devin J, Rosenstock J (2006) Effect of rimonabant, a cannabinoid-1 receptor blocker, on weight and cardiometabolic risk factors in overweight or obese patients: RIO-North America: a randomized controlled trial. Jama 295:761-775.

Pitler TA, Alger BE (1992) Postsynaptic spike firing reduces synaptic $\mathrm{GABA}_{\mathrm{A}}$ responses in hippocampal pyramidal cells. J Neurosci 12:4122-4132.

Rafiq A, Zhang YF, DeLorenzo RJ, Coulter DA (1995) Long-duration selfsustained epileptiform activity in the hippocampal-parahippocampal slice: a model of status epilepticus. J Neurophysiol 74:2028-2042.

Rinaldi-Carmona M, Barth F, Heaulme M, Shire D, Calandra B, Congy C, Martinez S, Maruani J, Neliat G, Caput D, et al (1994) SR141716A, a potent and selective antagonist of the brain cannabinoid receptor. FEBS Lett 350:240-244.

Schuchmann S, Schmitz D, Rivera C, Vanhatalo S, Salmen B, Mackie K, Sipila ST, Voipio J, Kaila K (2006) Experimental febrile seizures are precipitated by a hyperthermia-induced respiratory alkalosis. Nat Med 12:817-823.

Shafaroodi H, Samini M, Moezi L, Homayoun H, Sadeghipour H, Tavakoli S, Hajrasouliha AR, Dehpour AR (2004) The interaction of cannabinoids and opioids on pentylenetetrazole-induced seizure threshold in mice. Neuropharmacology 47:390-400.

Shinnar S, Glauser TA (2002) Febrile seizures. J Child Neurol 17 [Suppl 1]:S44-S52.

Stella N, Schweitzer P, Piomelli D (1997) A second endogenous cannabinoid that modulates long-term potentiation. Nature 388:773-778.

Straiker A, Mackie K (2005) Depolarization-induced suppression of excitation in murine autaptic hippocampal neurones. J Physiol (Lond) 569:501-517.

Toth Z, Yan XX, Haftoglou S, Ribak CE, Baram TZ (1998) Seizure-induced neuronal injury: vulnerability to febrile seizures in an immature rat model. J Neurosci 18:4285-4294.

Vasquez C, Lewis DL (1999) The CB1 cannabinoid receptor can sequester G-proteins, making them unavailable to couple to other receptors. J Neurosci 19:9271-9280.

Wada JA, Osawa T, Corcoran ME (1975) Effects of tetrahydrocannabinols on kindled amygdaloid seizures and photogenic seizures in Senegalese baboons, Papio papio. Epilepsia 16:439-448.

Wallace MJ, Wiley JL, Martin BR, DeLorenzo RJ (2001) Assessment of the role of $\mathrm{CB} 1$ receptors in cannabinoid anticonvulsant effects. Eur J Pharmacol 428:51-57.

Wallace MJ, Martin BR, DeLorenzo RJ (2002) Evidence for a physiological role of endocannabinoids in the modulation of seizure threshold and severity. Eur J Pharmacol 452:295-301.

Wallace MJ, Blair RE, Falenski KW, Martin BR, DeLorenzo RJ (2003) The endogenous cannabinoid system regulates seizure frequency and duration in a model of temporal lobe epilepsy. J Pharmacol Exp Ther 307:129-137.

Wettschureck N, van der Stelt M, Tsubokawa H, Krestel H, Moers A, Petrosino S, Schutz G, Di Marzo V, Offermanns S (2006) Forebrainspecific inactivation of $\mathrm{Gq} / \mathrm{G} 11$ family $\mathrm{G}$ proteins results in agedependent epilepsy and impaired endocannabinoid formation. Mol Cell Biol 26(15):5888-5894.

Wilson RI, Nicoll RA (2001) Endogenous cannabinoids mediate retrograde signalling at hippocampal synapses. Nature 410:588-592.

Wilson RI, Kunos G, Nicoll RA (2001) Presynaptic specificity of endocannabinoid signaling in the hippocampus. Neuron 31:453-462. 